\title{
Practical entomology : insects injurious to farm and garden crops, the character of the injury, the insect causing it, the remedy, briefly and plainly stated
}

\section{A. D. Hopkins}

W.E. Rumsey

Follow this and additional works at: https://researchrepository.wvu.edu/ wv_agricultural_and_forestry_experiment_station_bulletins

\section{Digital Commons Citation}

Hopkins, A. D. and Rumsey, W. E., "Practical entomology : insects injurious to farm and garden crops, the character of the injury, the insect causing it, the remedy, briefly and plainly stated" (1896). West Virginia Agricultural and Forestry Experiment Station Bulletins. 44. https://researchrepository.wvu.edu/wv_agricultural_and_forestry_experiment_station_bulletins/44 @ WVU. It has been accepted for inclusion in West Virginia Agricultural and Forestry Experiment Station Bulletins by an authorized administrator of The Research Repository @ WVU. For more information, please contact ian.harmon@mail.wvu.edu. 


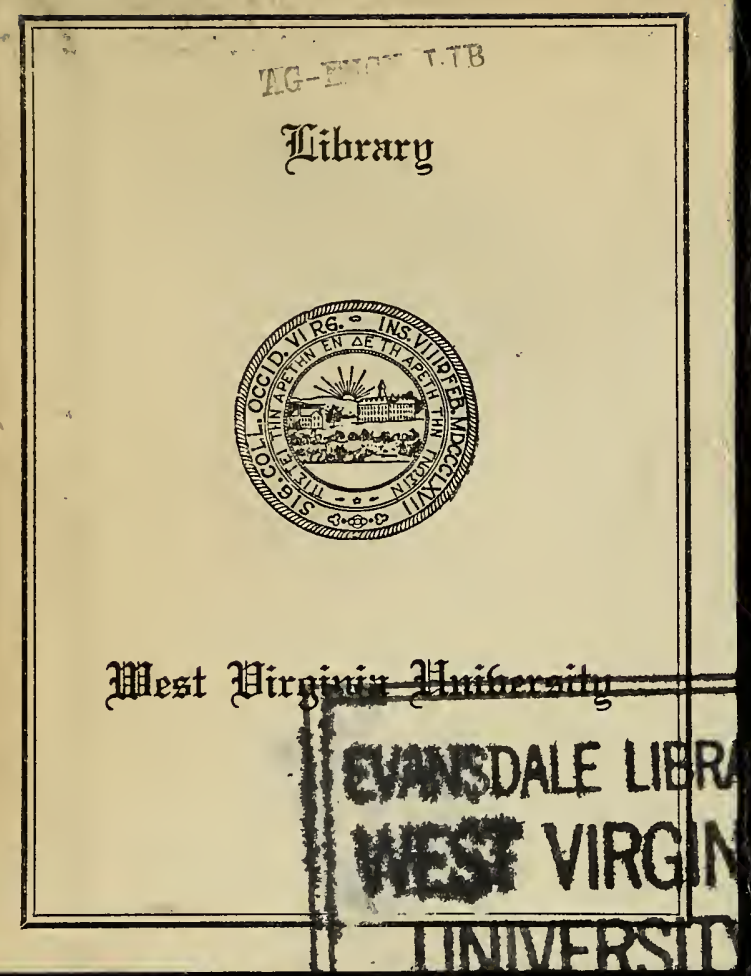

a 


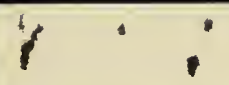

* Weś Kiginia University Library

"Fhis book is due on the date indicated below.

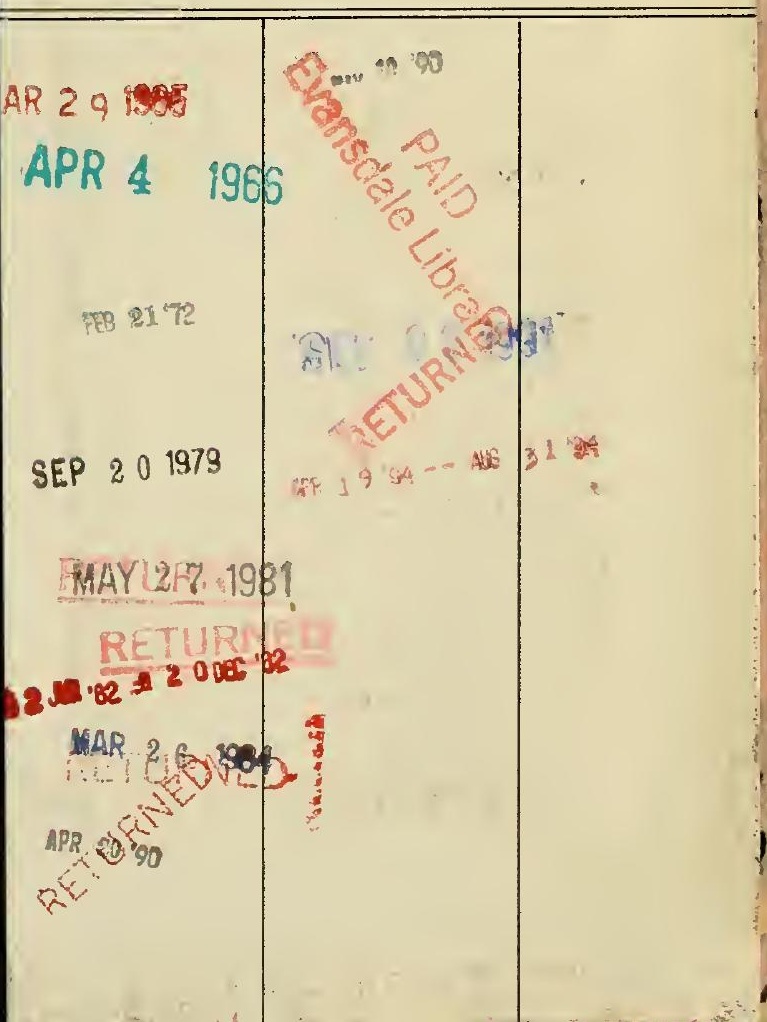


Digitized by the Internet Archive in 2010 with funding from

Lyrasis Members and Sloan Foundation 


\section{BULLETIN 44.}

West Virginia Agricultural Experiment Station. MORCANTOWN, W. VA.

\section{Practical Entomology.}

INSECTS INJURIOUS TO FARM AND GARDEN CROPS.

the CHARACTER OF thE INJURY. THE INSECT CAUSING IT. THE REMEDY.

BRIEFLY AND PLAINLY STATED.

A D. Hopkins and W. E. Rumsey.

A PRIL 1896. 
Board of Regents of the West Virginia University.

Name of Regent.

P. O. Address.

S. F. ReEd $\ldots \ldots \ldots \ldots \ldots \ldots \ldots \ldots \ldots \ldots$ Clarkshurg.

E. P. RuCKER............................... Welch.

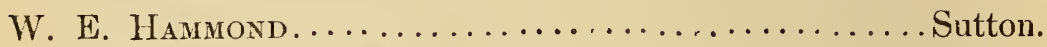

Chartes Burdette Hati..................... Wheeling.

Jaz. H. Stewart....................... Raymond City.

JAS. F. Brown . . . . . . . . . . . . . . . . . . Charleston.

John A. Robinson...................... Patterson's Depot.

C. L. Sигтн........................... Fairmont.

Geo. F. Evans........................... Martinsburg.

Members of the Station Committee.

John A. Robinson.

Cyarles Burdette Hart.

W. E. HaYMond.

President Board of Regents................ John A. Robinson. President University................J. L. Goodnight, LL. D. Treasurer...................... R Whitehil, Ph. D. Auditing Oficer........................ Joseph Moreland.

\section{Station Staff.}

John A. Myers, Ph. D.......................... Director. A. D. Hopkiss, Рн. D.................... Entomologist.

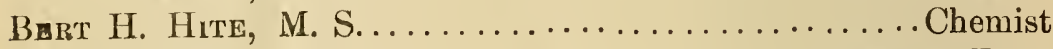

L. G. Conbett, B. S...................... Agr. \& Hort. W. E. Rumser, B. S. Agr.............. Asst. Entomologist. T. F. W Atson, B. S........................... Chemist.

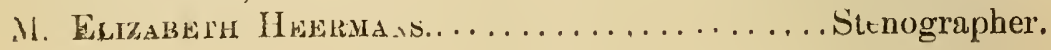




\section{Table of Contents}

Introduction

Page.

2.3

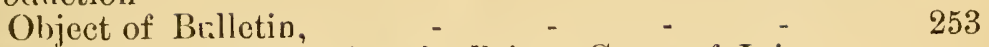

Difficulty in Determining the Prime Cause of Injury and Proper Remedy,

Insects Known by Their Work.

The Cause of the Trouble and the Rum r dy Determined by the Symptoms, - - - . -

Instructions,

Numbers,

Scientific Names,

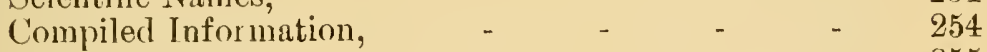

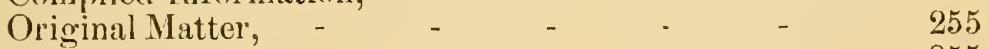

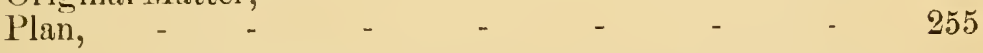

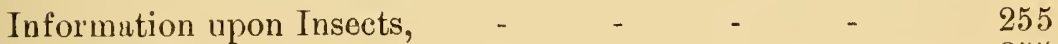

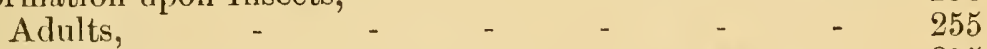

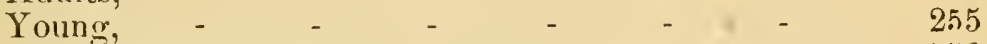

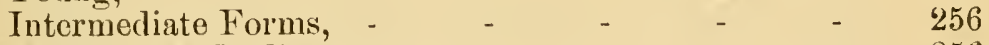

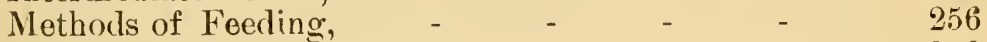

Insects 'That C'an be Poisoned, _ _ _ _ $\quad 256$

Insects That Cannot be Poisoned, - - $\quad 256$

Insects Injurious to Farm and Garden Crops.

Grasses,

Roots,

Stalks,

Leaves,

Seed,

Clover,

Roots,

Stalks,

Leaves,

Heads and Seed,

Hay, 
Wheat, Barley, Oats, Rye,

Seed,

Roots,

Stalks,

Leaves,

268

272

Heads,

Stored Grain,

Ir dian Corn,

Seed in the Gromud,

Roots,

276

Stalkn,

Leaves,

277

279

Ears,

251

Stored Grain,

281

283

Potato,

Planted Seed.

Stalks,

Leaves,

Stored Tubers,

284

284

287

287

289

Sweet Potatoes,

289

Roots,

Stalks,

Leaves,

Asparagus,

Stalks and Leaves,

289

290

290

291

291

Całbage, Kohl Rabi, Kale, Rape, Brussels Sprouts, Turnips, Rutahaga, Radishes, etc.,

Roots,

Stalks,

293

Leaves,

293

Cucumber, Melons, Squashes, Pumpkins, _ $\quad$ - $\quad$ - $\quad 296$

Roots,

296

Stalks,

Leaves,

Fruit,

296

248

300

Tomato,

Stalks,

Leaves,

Fruit,

Beans,

Seedi $n$ the Ground, 


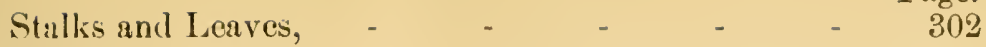

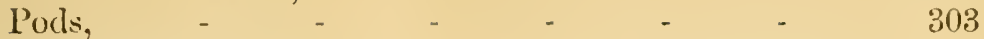

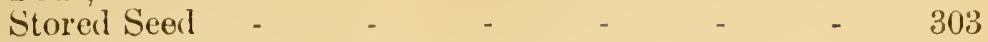

Pens,

Seed in the Ground, $\quad$ - $\quad$ - $\quad$ - 302

Stalks and Leaves, - $\quad$ - $\quad$ - $\quad$ - $\quad 302$

Poll-, -

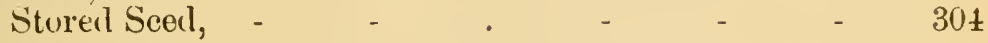

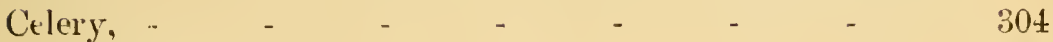

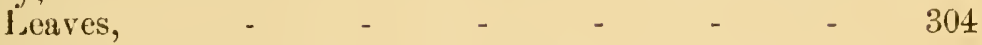

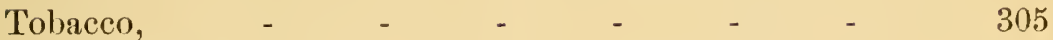

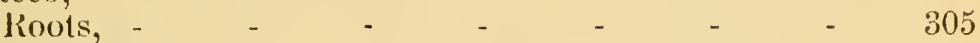

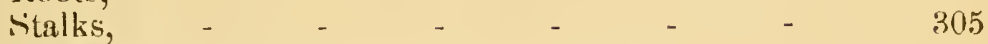

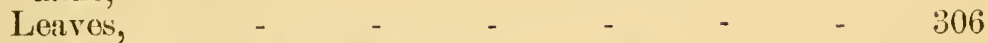

Dry Leaves and Manufactured Products, _ - - 306

Onions,

Roots or Bulbs,

307

307

Methods of Combatting Insect Pests.

Preventives,

High Culture and Clean Farning, _ _ _ _ 308

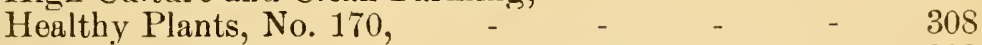

Clean Farming, No. 171. - $\quad$ - $\quad$ - $\quad$ - 308

Destruction of Rubbish, Etc., _ - - _ 308

Destruction of Surplus Products, No. 172, - 308

Destruction of Stubble, Etc., No. 173, - - - 308

Destruction of Weeds, No.174, - _ _ _ $\quad 309$

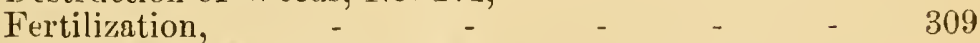

Home Made Manure, No. 175, _ $\quad$ - $\quad$ - $\quad 309$

Commercial Fertilizer's, No. 176, - _ _ $\quad$ - 309

Ashes, Tobacco Dust and Stems, No. 177, - _ 309

Farm Management,

Rotation of Crops, No. 17s, _ _ _ _ _ 309

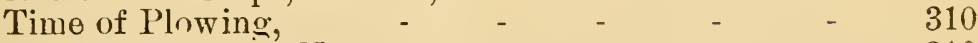

Summer Plowing, No. 180, _ _ _ _ _ $\quad 310$

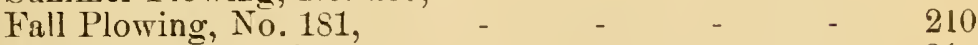

Winter Plowing, No. 182, _ _ _ _ _ 310

Deep Plowing, No. 183, - _ _ _ $\quad$ - 310 
Time and Methods of Planting,

Page.

311

Early Planting, No. 184, - $\quad$ - $\quad$ - $\quad$ - 310

Late Planting, No. 185, - $\quad$ - $\quad$ - $\quad 310$

Large Quantities of Plants Grown, No. 186, - 310

Harvesting,

Early Harvesting, No 187, _ _ _ _ $\quad 310$

Early 'l'hreshing, No. 188, $\quad$ - $\quad$ - $\quad$ - $\quad$ - $\quad$ - 311

Pasturing Strck, No 189, - $\quad$ - $\quad$ - $\quad$ - 311

Removal of Infested Proclucts. No. 190, - $\quad$ - 311

Clean Mows and Granaries, No. 191, _ _ _ 311

Feeding Surplus and Refuse Product, No. 192, - 311

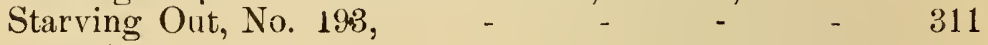

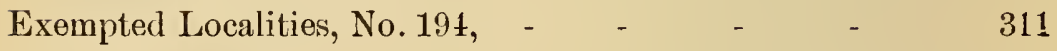

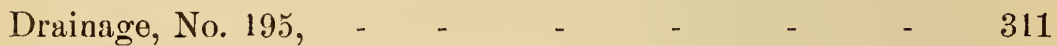

Destruction of Ants' Nests, No. 196, - _ _ _ 311

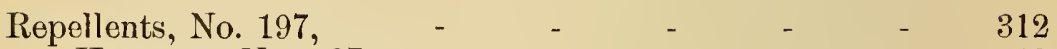

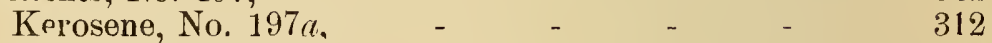

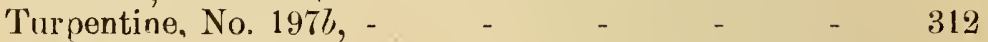

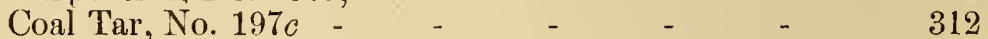

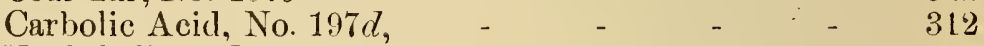

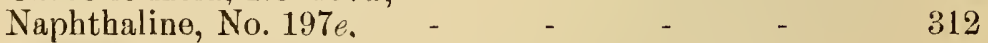

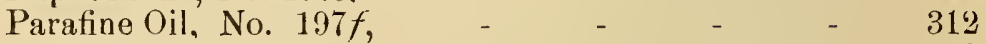

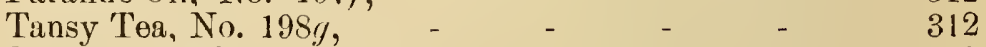

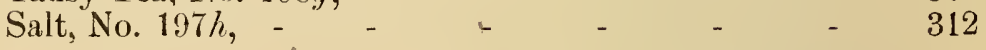

Fencing out,

Cloth, or wire netting, No. 198, - _ _ _ - $\quad 312$

Paper or tin boards, No. 199, _ _ _ _ _ _ 312

Boards coated with tar, No. 200, - _ _ _ _ 312

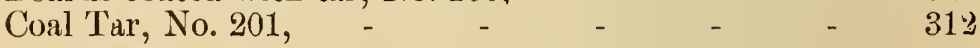

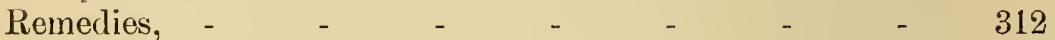

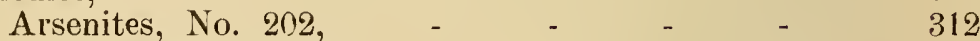

Paris Green, No, 213 , - $\quad$ - $\quad$ - $\quad$ _ $\quad$ - $\quad 312$

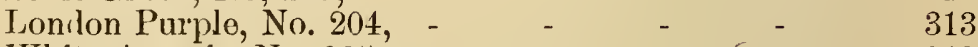

White Arsenic, No. 205, $\quad$ - $\quad$ - $\quad$ - $\quad$ - $\quad 313$

Arsenite of Lead, No. 206, _ _ _ 313

Arsenite and Copper Sulphate, No. 207, _ _ _ - 513

Corrosivo Sublimate, Nô. 208, - _ _ _ $\quad 313$

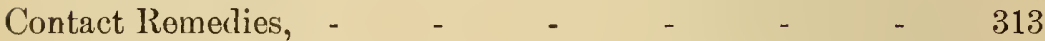

Kerosene Emulsion, No. 209, _ _ _ _ _ _ $\quad 314$

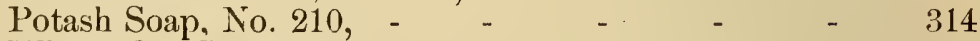

Whale Oil Soap, No. 211, _ _ _ _ _ $\quad$ - 314

Pyrethrum, No. 212, - $\quad$ - $\quad$ - $\quad$ - $\quad 314$ 
Tobacco, No. 212",

'Tobaceo Dust. 212h,

'Tobacco Stems, 212c,

'Tobacco Liquid, 212d,

Hot Water, No. 213,

Heat, No. 214,

Dust, No. 215,

Lime, No. 215\%,

Plaster, 215l.

Road Dust. $215 c$,

Ashes, 215d,

Poisonous Gases.

Bisulphicle of Carbon, No. 216

Miscellaneous Methods and Remedies.

Trapping, No. 217

Trap ( ropss, No. 218 ,

'Trap Crops of Wheat, No. 219,

Uncler Boards, No. 221,

Ditching, No. 222,

Hoperdozer, No. 223 ,

Windrows of straw, No. 224,

315

315

316

316

316

316

316

Baiting.

Puisoned Bait, No. 225,

Trap Crops, Vegetables, No. 226, _ _ $\quad 316$

Potatoes on end of Stick, No. 227, _ _ _ _ $\quad$ - 316

Handpicking, No. 228,

317

Adults, Eggs and Larve, No. 229, - _ _ $\quad$ - 317

Di vging or Cutting Out, No. 230, - - 317

Jarring and Benting, No. 231, - - $\quad 317$

Destruction of Infested Plants and Fruit, No. 232, 317

\section{Natural Enemies.}

Domestic Animals.

Hogs, No. 233,

Poultry, No. 234,

Young Chickens, No. 236

Other Live Stock, No. 237, _ _ _ _ _ 318

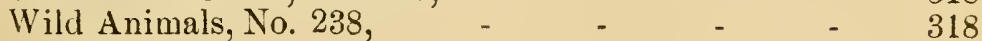

Skunks, No. 239, 
Toads, No. 240, Page.

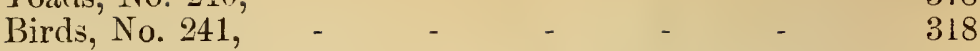

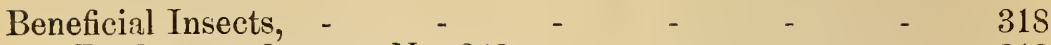

Predaceous Insects, No. 242, _ $\quad$ - $\quad$ - $\quad 315$

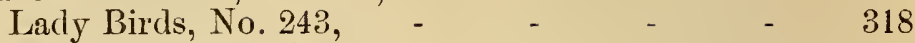

Ground Beetles, No. 244, - $\quad$ - $\quad$ - $\quad 318$

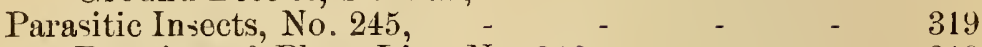

Parasites of Plant Lice, No. 246, - _ $\quad 319$

Parasites of Cabbage Worms, No. 247, - _ 319

Parasites of Caterpillars, No. 248, - _ _ $\quad 320$

Diseases of Insects, No. 249, - $\quad$ - $\quad$ - $\quad$ - 320

Disease of Clover Leaf Beetle, No. 250, - _ - $\quad 320$

Disease of Chinch Bug, No. 251, _ _ _ _ _ $\quad 320$

Disease of Cutworms, No. 252, - $\quad$ - $\quad$ - 321

Disease of Grasshoppers, No. 253, 321

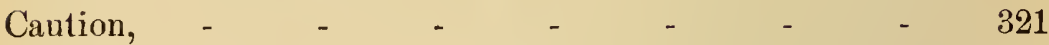

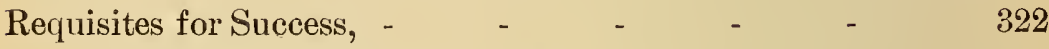

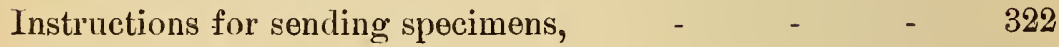

Spraying Machinery, etc., _ $\quad \ldots \quad \ldots \quad \ldots \quad \ldots$ 


\section{Introduction.}

This bulletin is prepared espocially for the busy practical farmer and gardener who desire a work of roference containing realily accessible, and plainly stated information upon so:ne of the moro important facts with reference to insect injuries to cultivated plunts. It is also intenderl to be of service to the young student of economic entomology who desires a simple guide to the study of the common insects and the character of their work.

\section{Difficulty in Determining the Prime Cause of Injuries}

\section{and Proper Remedies.}

The grower of farm and garden crops as well as the young entomological student is often at a loss to determine whether or not a given trouble is the work of insects. Even when it is known that a trouble is caused by insects, it is often difficult, if not impossible for one who is not experieneed in entomological questions, to decide, with any degree of accuracy, what particular kind of an insect is the prime cause of it. E⿰pecially is this difficult and confusing, when, as is sometimes the case, a large number of different kinds of insects are associated with the injury, or occur on the injured plants. 'Thus, it often occurs that the wrong' insect is blamed for the trouble, and a remedy is applied that does more harm than good.

The character of a trouble affecting a plant, a growing crop or a stored prodnct, is the first thing to attract the attention of the grower, but in order for him to determine, from the usual form of publisherl descriptions, what remedy to apply, he must first find the insect that caused it, and then determine the name of the pest, and by means of this, search for the desired published information. Ordinarily, this is a tedious process for any one but an entomologist, the greatest difficnlty being to find by description, the name of the insect, especially if the descriptions include scientific names and technical terms.

\section{Insects Known by Their Work.}

As a rule, every kind of an insect enemy of plants has some pe. culiar habit of attack and manner of feeding, that causes the infested plant to show some peculiar condition or symptom, by 
which the insect causing it may be determined. In fact, it will often indicate what remedy to apply even if the insect is not observed.

\section{The Cause of a Trouble and the Remedy Determined by the Symptoms.}

It is the object of the plan followed in this Bulletin to simplify the matter by making the characters of. a trouble the prime features to guide the reader to an account of the cause and the remedy, just as the name of a dise sse and the remedy is determined by the character of the symptoms.

\section{Instructions.}

If a trouble appears, affecting cultivated plants, note the general appearance of the plant, the character of the injury, and the kinds of insects associated with it. Then refer to the general characters given in this Bulletin under the name of the plant, and to the special characters under the namo of the part of the plant that is injured. Then by means of the numbers, refer to and examine the brief descriptions of the insects, and if all of the descriptions agree with the characters of the trouble, and of the insects found with it, examine the preventives, remedies, etc., referred to by the numbers.

\section{The Numbers.}

The references are made back and forth by means of numebers to 9 void the frequent repetition that would otherwise be necessary. The reader in tracing up these numbered reforences will find it convenient, and avoid possible mistakes-when ther'e are several references to one line of subjects-by copying the numbers on a slip of paper.

\section{The Scientific Names of Insects.}

The scientific names of the insects mentioned are included in foot notes for the benefit of those of our readers who may desire to know them and to indicate to the entomological reader what particular insect is referred to by the common name.

\section{Compiled Matter in Small Type.}

The portion of this bulletin that appears in small type is compiled from the writings of the best entomological authorities, and refers to subjects that have not come under our observation. This information was selected and compiled mainly by the junior author. 


\section{Original Matter In Ordinary Type.}

The portion that appears in ordinary type was prepared by the senior anthor mainly from persomal studies and verification of the subject treated.

\section{The Plan.}

The plan followed in this Bulletin wis suggested by that of a recent publication on corn insects, by Professor S. A. Forbes, state Entomologist of Illinois*. A somewhat different arrangement is here adoptod, however, and some or iginal foutures introduced, with a hope that something will be added to the uscfulness of this class of entomological publications.

There is yet room for considerable improvement along this line, and the observing farmer and gardener in his correspondence with the Entomologist can, from a practical standpoint, doubtless, make some valuable snggestions and contribute important information that will materially aid in improvement of future bulletins on "Practical Entomology," which we hope to issue, from time to time.

\section{General Information upon Insects.}

\section{The Adult Forms of Insects.}

The adults or perfect forms of insects have six logs and nsually have wings. Bees and the insects belonging to this class have four wings, except a few kinds that are wingless. Flies have two wings, with a fow forms that are destitute of these organs. Butterflics and Moths have four hroad wings, with the exception that females of some species are wingless. Beetles have two hard-shelled wing covers and tro thin, folding wings. Bugs have four wings, except a few that are wingless, and in one group of this class of insects the wing covers are thickened at the base, overlapping each other when folded, and thin at the outer ends, while in another group the wing covers are of the same thickness throughout and when not in use, usually slope at the sides of the body, roof-like. The under wings in both cases are thin and transparent.

Plant Lice or Aplials: adults of the same species may be winged or wingless - the winged forms having two pairs of thin ones. Grasshoppers have two wing covers and two thin, folding, under wings.

\section{The Young Forms of Insects.}

The young or growing forms of insects are known by the technical name of larva, plural larect. The common names for the

*A Monograph of Insects Injurious to Indian Corn, Part 1. In 18th Report of the State En. tomologist of Illinols, 1891-2. 
young of bees are maggots, slugs and worms ; the young of Hies, are ungegots; the young of Beetles, grubs or worms; and of Butterflies, caterpillars or worms. The young of Grasshoppers, bugs and plant lice, are called nymphs and resemble the adult, excopt that they are wingless and of various sizes.

\section{The Intermediate Forms.}

Most young forms of insects when full grown cease feeding and change to a inactive form called the pupa-plural prepre, which is usually enetosed in a silken or earthen case called its pupa case or cocoon. This inactive form of Bees, Beetles and Hlies has no common name, hence is referred to by the technical term. This stage of Butterglies and moths is called the chrysalis. The intermediate form of the true Bugs, Grosshoppers and Plant Lice difters but slightly trom the young stages, and like them are active and feed, diffuring in this respect from the pupre of bees, thies, beetles and butterflies.

\section{Nethods of Feeding.}

The adults of butterflies and moths suck their food, but are not injurious. Their young bite and consume their food and are among the most injurious insects. Both the adults and young of bettles bite their food, some of them feeding upon plants and others on insects. The adults of flies bavo month parts formed for piercing and sucking; the mouth parts of some of their young are rormed for biting, while that of others are formed for sucking. some flies are enemies of plants, while others are parasitic and feed upon insects. Some of the adults of bees have mouth parts formed for sucking, while cthers bite the substance upon which they foed. Some or the yuung of bees have biting, while others havo sucking mouth parts and foed upon both plants and insects. The bugs and plant lice in all of their stages have month parts formed ror sucking, while all stages of the grasshoppers and locusts have mouth parts tormed for biting.

\section{Insects that Can Be Poisoned.}

Nearly all insects that have mouth parts formed for biting may ber poisoned, if it is possible to apply the poison to the substance upon which they feed.

\section{Insects that Can Not Be Poisoned.}

Insects that suck their food from beneath the surface of their foad plant, cannot be killed by poisons, but can be killed with liquids, powder's and gases, that cause death by coming in contact with the surface of their bodies or breathing pores. 


\title{
INSECT INJURIES TO FARII AND GARDEN CROPS.
}

\author{
BY A. D. HOTKINS AND W. E. RUMSEY.
}

TH E G R A S E S,

INCLUDING ALL OF THE CULTIVATED KINDS.

\section{THE ROOTS.}

The plants are stunted and fail to make normal growth in good soil; they wilt or die in patches, or the sod is easily separated from the surface soil.

If the plants wither or die, and the ronts are cut off so the sod can be rolled up like carpet, and white grubs are common, seo No. 1.

If the plants are dwarfed and grub worms are not present, see Nos. 2, 3, 6 .

If whitish blne plant lice are common on the roots, see No. 6 .

If slender, shining, wire-like worms are present, see No. 2.

If large, dirty-brown maggots are common in the soil, see No 3.

If the stalks and roots are cut olf at or above the crown of the roots, see Nos. $1,4,5$.

\section{Injury by the Young of Beetles.}

The sod dies in patches, or the grass has a dwarfed, unthrifty appearance.

1. The White Gruts. -Soft-boclied, whitish grubs with brownish or reddish beuds, and with six smali logs noar the head; hinder portion of the body thick and smooth; when disturbed they curl up so the head touches the tail end, common in sod lands.

There are many linds of white grubs, all closely resembling each other, some of which simply feed on manure and decaying vegetable substance, whilo other's feed on the roots of plants. Those feeding upon roots vary in size when matured, from onehalf to two inches long, and may usually be distinguished from those that feed in manure by their reddish beads, especially the larger and more destructive kinds.

1. Numerous species belonging to the following genera: Lachnosterna, Csclocephala, Als lorhina, Prionus and Macrodactylus. 
All these different kinds of grubs change to beetles like the June bug, May beetle, dung beetle and rose bug.

The female beetles of the injurions kinds lay their eggs usually in grass land, from Nay to July. The young grubs feed npon the roots, and remain in this immature stage from one to three years, varying with the different species. They then cease freding and change to an inactive form called the pupa.

W hite grub worms are common in West Virginia and may be classed among our worst insect pests, attacking corn, grass, wheat, and other small grain, potatoes and other vegetables.

For remedies, etc., see Nos. 175, 178, 181, 228, 233, 239 and 253.

2. Wire Wrmms ${ }^{1}$.-Slender, brownish, shining, hard-bodied worms, one-half to one-fourth inches long, resembling somewhat a piece of rusty wire; consume or bore into the ronts and base of the plant; the young of click bcetles or "snapping bugs."

The eggs are laid by the adult beetles in grass land. They remain in the worm stage about two or three years, changing to dormant forms about July of the second or third year, remaining in this stage about three weeks, when they change to beetles which remain in the soil until the following spring, when they emerge to deposit eggs for another brood.

Wire worms of many kinds are common in West Virginia, and are serions pests, attacking the same kind of plants as does the white grub.

For remedies, etc., see Nos. 175, 178, 180, 181, 193, 195, 227.

\section{Injury by the Young of Flies.}

3. The Meadow Maggots, ${ }^{2}$ - Large, dirty brown, footless worms, or maggots, from one-half to one inch long, common under dead grass and in damp places during early spring; also common in sod where they are supposed to do considerable damage by feeding upon the roots. They change to large, mosquito-like flies with very long legs and occur in great numbers flying over meadows and other grass land in the spring and fall.

The egges are deposited by the flies in grass land during the spring. These hatch in a short time into small blackish maggots that feed upon the roots, grass and other plants until they are full grown when they change to a chrysalis forms from which a fall brood of flies emerge; another set of eggs are deposited, and the young hatching therefrom remain in the ground over winter.*

These insects, of which there is a large number of species, are extremely common in portions of West Virginia, often occurring in the early spring and fall in immense swarms, especially in flat, undrained meadow and pasture lands.

For preventives, remedies, etc., see Nos. 195, 234.

1. Numerows species belonging to the following genera: Cardiophorus, Drasterius, Agriotes, Melanotus and Asapbes.

2. Numerous species Tipulidae. *Compiled. 


\section{Injury by the Young of IToths.}

Stalks and roots severed at or below the crown of the roots.

4. Cutwoms-(Seo No. 7). Young cutworms evidently do considerable damage to grass roots.

5. Web Worms.-(See No. 8) are also classed among the enemies of the grass roots.

The damage to meadows and pasture by cutworms and web worms feeding upon the roots of grass is doubtless considerably greater than is generally supposed.

\section{Injury by Plant Lice.}

6 The Grass Root Lonse, ${ }^{1}$ - A whitish or yellowish plant lonse, without honoy tubes on the hinder part of its body, but with a pair of minute, circular openings instead, thus differing in appenrance from the Corn Root Louse. It attacks the roots in the same manner, however, and is attended by ants. 'The life history is not known, but it is probably similar to that of the Corn Root Louse. Soe No. 71.

This insect, or one similar to it, has been observed in Wood county, where it was quite injurious to grass in the meadows.

For preventives, remedies, etc., Sco No. 178, 196.

\section{THE STALKS.}

Stalks sovered near the ground; central shoot dies and turns yellow; leaves of stalk wholly or partly consumed, or the plants huve a sickly appoarance. If stalks are cut off near the ground, seo Nos. 7, 8. If the central shoot or the upper joint and head dies, see Nos. 9, 10, 11.

If the stalk and leaves are wholly or partly consumed, see Nos. $14,15,16,17$.

If the plants have a sickly apperrance and are covered with lice or small stinking bugs, seo Nos. 12, 13.

\section{Injury by the Young of Moths.}

Stalks cut of and left on the ground or the central shoot dies.

7. Cut Worms. ${ }^{2}$-Soft-bodied, greasy looking worms, varying in length when full grown, from one to nearly two inches, of a dingy brown gray, or greonish color, with indistinct longitudinal markings, and provided with sixteen legs. When removed from the soil they curl themselves up in the same manner as does the

1. Schizoneura panicola. Thos.

2. Numerous species belonging to the following genera; Agrotis, Mamestra, Hadena, Lapnygma, Prodenia and Nephelodes. 
white grub. They eat into or cut off the hase of the plant beneath or above the surface, or consume the entire plant.

Thoy feed principally at night and during warm, cloudy days, and changing to a brown, smooth and shining chrysalis from which dull, grayish moths omerge in the spring and summer.

There are a great many kinds of cut worms that attack grass, corn, \&c., all having somew hat similal habits, and although the life histury of each suecies differs somewhat, it may be generalls stated as follows:

The eggs are raid by the female min-usuall ${ }^{\circ}$ on grass; when the eggs hatch ihe young wormis enter the ground and feed upon the tender shoots and rnots of grass and other plants. Upon the approach of Winter they bury themselves in the soil and remain there until Spring, when they become active and attack almost any green vegetation they find, often traveling a considerable distance to find it, or climb the stalks of plants io feed upon the leaves. They become full grown by the first hot days in May and June, when they cease feeding and burrow for some distance into the soil where they form a cell in which they change to brown, smonth aud shining chrystalies, frrm which, in three or four weeks, the adult moth emerges to deposit eggs for another brood.

Cut worms are among our very worst insect enemies of farm and garden plants in West Virginia, and during the spring and summer of 1895 , they were especially destructive in the Uhio Valley, where it was necessary to replant corn, potatoes and other crops a number of times before a stand could be secured. The loss to farmers occasioned by the deprerlations was enormous.

For' preventives, remedies, etc', seo Nos. 173, 181, 197b, 199, 228 , $225,234,241,239,252$.

8. The Web-Worms ${ }^{1}$, Whitish, pinkish or brownish worms, one-half to one inch long, covered with tufts of bristly hairs; living in a tube constructed of webs attached to the side of the stalk; feeding during the night upon the base of the stalk beneath the surface of the ground.

These pests are the young of white or yellowish moths, with narrow, satin-like wings; common flying in meadows and pasture fields in late summer and fall; their wings fold close to the body when at rest.

The eggs are deposited by the moths near the roots of grass from July to October; hatching in about a month, the young feed as do cutworms, on the tender shoots and roots of grass, and remain in the ground over winter to attack grass and corn in the spring, and reach their full growth in May and June, then changing to chrysalis from which moths emerge to deposit more eggs. *

There are a great many kinds of this class of insects known to infest grass, some of them also attacking corn and other plants. Within the last year or two they have become extremely destructive to corn in portions of West Virginia, especially in the connties bordering on the Ohio river. They were also common corn pests in Monongalia county during the spring of 1895 .

For preventives, remedies, etc., see Nos. 181, 197h, 199, 225, $230,248$.

1. Numerous species belonging to the genus Crambus. *Compiled. 
9. The Stalk Borer.-See No. T3. Very young oxamples, evidently of this insect, have heen oloserved in blue grass stalks feed ing on the base of the "pper joint, causing "White 'Top)."

\section{Injury by Two-Winged Gnats}

The central shoot or head dies and turns light yellow.

10. Stem. Mugyots, (sco No. 40.)

11. Injury by Thrips, - (see No. 43,) cansing the same conditions as the Stem Maggots and Stalk Borer's.

\section{Injury by True Bug and Plant Lice.}

Plants dwarfed and sickly and covered with small, reddish or black bugs.

12. The Chindh Buy-(See No. 45.) Often a sorions pest.

13. I'lant Lice.-(See No. 56.) Aro sometimes quite injurious, but the injury is seldom noticed.

\section{THE LEAVES.}

Leaves partly or wholly consumed, presenting a rageed appearance, or shriveled and whitish. If grasshoppers are common soe No. 16, 17. If grasshoppers are not common, and smooth, yellow striped caterpillars are found in large numbers, see No. 14.

If the injury is done at night, see No. 16. If leares are shriveled and whitish and covered with small stink bugs or green lice, see Nos. 18, 19.

\section{Injury by the Young of Moths.}

Leaves partly or wholly consumed.

14. The Ammy Worm, ${ }^{1}-\mathrm{A}$ dingy, hlack-colored worm, one and three-fourths inches long, with black and yellow stripes on its back, and with the lower part of the body greenish; when abundant, consuming the leaves on all of the plants in its line of malreh. The worm changes to a brown moth, measuring about one and three-fourths inches from tip to tip of wings, when expanded.

The eggs are deposited by the moth on grass or growing grain in the spring; and hatch into greenish worms which sulsequently take on a darker hne. The worms continue to feerl for two to four weeks and when the plants upon which they feed are destroyerl in one section, they move in al holy in search of food, destroying all growing grass or grain that eomes in their way. When they have attained their full growth they burrow into the ground and chatnge to uhrysatids and remain there until spring, when the noth emerges. Some of the moths may emerge in the fall and pass the winter in that form.

This insect doubtless occurs in Wrest Virginia, but we have no

1. Lencania unipuncta. 
information of its having done serious damage to grass or other crops. It is liable to appear, however, whenever the conditions are favorable for it.

Preventatives-remedies see Nos. 171, 181, 182, 200, 201, 222, 225.

Climbing Cutworms. (See No. 7.) Cut worms with climbing habits may do considerable damage.

Many other caterpillars, the young of various kinds of moths, feed upon the leaves of grass, but are not especially destructive.

\section{Injury by Locusts and Grasshoppers.}

Leaves and portions of the stalk wholly or partially consumed, presenting a ragged appearance.

\section{Short Horned Grashopper.}

16. The Eastern Red Legged Lncust ${ }^{1}$-The adult a brownish, medium sized hopper about one inch long with short antenne, or horns, with pale under wings and with the second joint, from the body, of the hind logs a bright red. The young vary in size from minute, flea like hoppers to the size of the adult and vary in color from gray to yellow. The young forms are distinguished from the adults by the absence of fully developed wings.

The eggs are deposited in the pou-like masses just beneath the surface of the ground, in the latter part of the summer or early autumn. The eggs remain in the ground over winter and hatch in April and May.

This species is a near relative of the Rocky Mountain Locust which has from time to time caused great destruction of crops in the Mississippi Valley.

This eastern species often occurs in immense numbers in restricted localities in West Virginia, and has at times caused considerable alarm. It was especially abundant in Mineral county in 1891; also in a field near Morgantown in 1895, and has been reported from time to time from other sections.

For preventives, remedies, etc., see Nos. 223, 225, 235, 241, 252a.

\section{The Long-Horned or True Grasshoppers.}

17. The Meadow Grasshoppers. ${ }^{2}$-Medium sized green or greenish, long winged, long horned, and long legged grasshoppers, with somewhat similar life history and habits to that of the Locust.

There are a great many species, but none of them occur in sufficient numbers to alone cause much trouble, but co-operating with each other and with the locusts they often do serious damage. Remedies same as for locusts.

1. Melanoplus femur-rubrum.

2. Locustidx. 
Grass, Heads and Seed.

\section{Injury by Bugs and Plant Lice.}

Leaves shriveled and sickly, covered with lice and bugs.

18. The Chinch Buy, (seo No. 45.)

19. Plant Lice, (seo No. 56.)

\section{THE HEADS.}

Heards are eaten or cut of.

20. The Army Worm, see No. 14; also Grasshoppers, 16, 17 and Climbing Cutworms (?) No. 15, 20a.

20a. Climbing Cutworms. See No. 7.

About the year 1876 , in June, a dark colored worm made its appearance in Jack -on county, cutting off and eating the young heads of timothy at night. Probably it was one of the climbing cut worms.

\section{THE SEED.}

Injury by the Young of BeEtles.

21. The Meal Worm. ${ }^{1}$ - A slender, hard-shelled, smooth and shining, redish-brown worm, about one inch long, common in hay seed on barn floors, evidently feeding upon the seed. This worm changes to a black beetle about five-eighths of an inch long.

This insect often occurs in great numbers under loose boards, boxes or barn floors. The damage by it is not great, however, except where the seed is desired for sowing

For preventives, remedies, etc., seo No. 191.

\section{CLOVER.}

\section{THE ROOTS.}

The plants wilt and die, or dwarfed and fail to make normal growth in good soil.

1. Tenebrio_molitor. 
If the plants wilt and are easily pulled up, separating just below the erown, and the main root is hollowed out or filled with borings, see No. 22.

If the plants are stunterl and the roots are not hollowed out, see No. $23 a$.

If eaten off, see No. 23.

\section{Injury by Beetles or Their Young.}

BORING IN THE RoOTS.

22. The Clover Ront Borer ${ }^{1}$ - A small brownish or black cylindrical beetle, one-tenth of an inch long, boring in the main root and crown of red clover. The young, a small white grub, oneeighth of an inch long, feeding on the inner portion of the root.*

In the spring the beetles bore into and deposit their eggs in the crown of the roots and in a few days the larva hatch and burrow downward, feeding in the main root and mining into the larger branching ones. During the latter part of the summer they reach full growth and changing to the pupa within the roots, shortly after emerge as adults. There is probably more than one brood of this insect in a year. They pass the winter in the roots, in their different stages, and the adults appear in the spring. +

This is an extremely destructive insect in some sections of the country, and doubtless occurs in West Virginia, but has not been observed by us or reported by correspondents. Clover growers in the State should look out for it and if found, report the fact to the Station.

No successful remedy known.

23. The White Grub, (see No. 1, 23a.) and Wire Worms (see No. 2,) may do some clamage to the clover roots and thus prevent the perfect development of the plant.

\section{THE STALK.}

The stalks are nined, cut off noar the ground, or the tender portions consumerl.

If the stalks are injured by an insect mining through the pith, seo No. 24.

If cut off, soo No. 25.

If consumed, see No. 25 .

\section{Injury by the Young of a Beetle.}

Slender Worms Mining in the Stalk.

24. The Clover Stem Borer'.-A cylindrical, slender, whitish or yellowish worm, about one-half of an inch long, mining in the pith of the stalk or stem of red clover; changing to a small, slencler beetle, about one-fourth of

1. Hylastes obscurus, Marsham.

2. Languria nozardi, Fab. *Compiled, tCompiled. 
an inch long, with its head and front portions of its hody yeilowish-red and the muller portions shinimg, hhish hlark

'This beetle deposits her aggs on or in the onter portion of the stem of clover, rage weed, and many other plants; the larvat feeding on the pith, and as a rule, remaining in the base of the stem mntil spring, when it ehanges to the pulpa and adult.

This is a common insect in West Vir qinia, lut is not known to he especiully injurious to clover, the common rag weed appearing to be its favorite food plant; the lar've occurring ynito common in tho dry weed stulks during the winter and early spring.

For preventives, remedios, etc., soe 171,174 .

25. C'uturmms. No. 7, Army worm, No. 14 and Grasshoppers No. 1 , are all injurious to the stalk and may at times prove very destructive.

\section{THE LEAVES.}

Leaves consumed, full of holes or have a ragged appearance.

If the leaves are full of holes and have the elges eaten out, or the plants are entirely defoliated and no insects are visible through the dry, see No. 26.

If the leaves have a ragged appearance and grasshoppers are aloundant, see No. 27.

If the leaves are only moderately injured, see No. $29,30,32$.

If the leaves and a large part of the plant is consumed and smooth, striped worms are common, see No. 28.

If loaves are folded or webbed togethor, see No. 31, 33.

\section{Injury by the Adult and Young of a Beetle.}

Leaves full of holes and edges of leaves eaten out by beetles and greenish worms.

26. The Clover Lerif Beetle.-A lark brown, snout beetle, abont three-eighths of an inch long, feerling on the leaves at night, eating holes in them and hiding under leaves, rubbish, otc., during the day; the young or larva is a greenish, legless grub, about onebalf un inch long, feeding on the edge of the lenves; enting out circles as if cut ont with a punch. Like the beetle the young feed at night and hide duing the day.

The eggs are reposited by the female at the rate of 200 to 300 on the plants in the spring and latter part of smmmer. The spring hrool appears in May and the larvae reach their full growih in seven or eight weeks, when they make their cocoons, usually in the soil, just beneath the surface and the beetles emerge abont a month later.

The eggs deposited by this summer brood of beetles soon hatch, and the worms continue to feed until cold weather, some of them possibly changing to pupae and adults, while others remain in the larvae stage until spring, when they attack the young clover.

'ihis is a foreign pest and a new one in West Virginia, first at-

1. Phytonomus punctatus, Fabr. 
tracting attention on account of the destruction wrought by it in Berkeley and Hampshire counties in May, 1894.

It makes its appearance in the spring in enormous numbers, and were it not for a disease that is very dostructive to it, it would hardly be worth while to try to grow clover in localities where it has once been establiched.

See diseases, No. 250.

27. Grasshoppers and Locusts, (see Nos 16,17.) are of ten quite destructive to young clover in the spring, causing the leaves to have a ragged appearance when they are not entirely consumed.

\section{Injury by the Young of Moths and Butterflies.}

28. The Army Worm, see No. 14.

29. Climbing Cutworms, see No. 7.

30. The Clover Leaf Folder.-A small, greenish caterpillar, folding and webbing tue leaves together.

31. The Clover Looping Caterpillar2.--A kind of looping or measuring worm, changing to a gray molh that is very common in meadows, flying up as we walk along through the grass. Common in West Virginia.

32. Caterpillars of Butterflies.-Small, greenish or yellowish caterpillar's, the voung of the common Lemon yellowe ${ }^{4}$ and Opange yellow butterflies, the small Triled blue butterfly ${ }^{6}$ and the brown Sileer spotted shipger butterfy and other similar larva feed upon the clover leaves and donbtless do considerable damage. All are more or less common in W'est Virginia.

\section{Injury by the Young of a Gnat.}

33. The Clover Leaf Midge. - A minute maggot living in the leaves, with habits similar to No. 34. Has not been observed by us in West Virginia.

\section{THE HEADS AND SEED.}

Heads dwarfed, and greenish when they should be in bloom, and seeds fail to develop.

\footnotetext{
1. Hypena seabra.

2. Drasteria $\mathrm{sp}$

4. Eurymus philodice.

5. Eurymus eurytbema.

6. Thecla Calauus.

7. Epargyreus tityrus.

8. Cecidomyia trifolii.
} 


\section{Injury by the Young of a Gnat.}

34. The Clorer Seed Midye:-A minute, orange-colored maggot, about one-tenth of an inch long, feeding on parts of the flowers and on the tender growing reed; changing to a minnte two-winged gnat.

'ihe egos are deposited by the gnat in the heads; these hatching, the young feed at first upon the tender, inner portions of the flower, and later upon the seeds, from which they suck the hiquids and thus prevent their develogment. Whe'n the maggots are full grown they leave the heads and fall to the ground where they chinge to pupa and the gnats soon appenr to deposit more eggs. There are two or three generations each year.

'This is an extremely destructive insect in certain sections of the country, making clover seed growing for market impossible. It has not been observed or reported to us in West Virginia, but doubtiess occurs in the State.

For remelies, preventives, etc., see No. 187, 189.

\section{THE HAY.}

Hay in stacks and mows containing white, silky webs and excrements resembling coarse gunpowiter.

\section{INJURY by THE Young of A Moth,}

Feeding upon the leaves of the hay in the stack or mow.

35. The Clover IIay Tomm².-A brown worm or caterpillar about one-half of an inch long, living in clover hay, which it, webs together and feets upon the leaves; changing to a pretty purple and golden marked moth, expanding abnut four-fifths of an inch.

The eggs are deposited by the moth upon the hay, the larve hatching therefrom feed upon it and lecome full grown in a few weeks, then make silk cocoons in which they change to the chrysalis stage and soon appear as moths.

This insect is, as a rule, more liable to attack hay that has been allowed to stund over one or more years in stacks or mows; usually more abundant in the bay near, or at the bottom. 'This is a common pest in West Virginia.

For preventives, remedies, etc., see 190, 191, 192.

WHEAT, BARLEY, OATS AND RYE. THE SEED IN THE GROUND.

If the seed in the ground fails to germinate, it may have been

1. Cecidomyia leguminicola, Lint.

2. Pyralis costalis, Fab. 
destroyed by Ants No. 62 ; Wire Worms, No. 2 ; Grub Worms, No. 1 ; or Fungous Gnats, No. 88.

\section{THE ROOTS.}

If the plants turn yellow or wither and die, the canse may be due to the work of Wire Worms, No. 2; Gruh Worms, No. 1; Corn-root Worms, Nos. 69, 70 ; Root Lice, No. 71 ; Cut Worms, No. 7 ; or Meadow Maggots, No. 3.

\section{THE STALK.}

If swellings and blister-like plase-nceur on or near the joints, and some of the joints thus affected are hent over, see Nos. 36,37 .

If the stalk breaks off near the ground and upon examination a large burrow has been made through the joints, see No. 38. If the base of the -talk is shriveled and olijects like flax seeds are found under the sheath of the leaf, see No. 39.

If the top or upper joint and heal dies and turns white, is cut. off, or spiral mines oceur in the straw beneath the sheath, see Nos. $40,41,42,43,44$.

If entire stalk dies and mines at the base extend into the ronts, see No. 49.

If the top dies and holes are bored in the side of the stalk, see No. 44.

If the base of the upper joint shrivels and minute, slender, black insects vecur uncler the sheath, seo No. 4:3.

If the plants have a sickly appearance, turning whitish in patches over the fielcl, and the stalks aro covered with minnte red, and larger black stinking bugs, see No. 45. If covered with greenish plant lice, see No. 46 .

If young plant takes on a darker green hme in patches over the field, fail to bearl ont and finally turn yellow or brown and flax seed objects vecur under the sheaths, see No 39.

If the leaves or stalks are eaten, seo Nos. 47,48 .

\section{Injury by the Young of Four-Winged Gnats.}

Small maggots causing galls or swellings on the joints Nos. 36-37 or slencler worms mining in the stalks causing the upper portion of entire stalk to die. No. 38.

36. The Joint Trom ${ }^{1}$. - A yellowish-white maggot one-fifth of an inch long, living in swellings on the joints and sheaths, changing to a minute four-winged gnat. *

The eggs are laid by the gnat in the stem near the joints, and they develop in the swellings or gal's that form over them. The maggots are supposed to pass the winter in the galls or in the stub-

1. Isosoma hordei, Harris. *Compiled. 
ble, in tho ficld and in the straw stack; the adults emerging in the spring. *

This insect oecurs in Wrest Virginia, but no special complaint has been made of injury by it. It has from time to time proven a serinus pest in other soctions of tho country.

For preventutives soo Nos. 173, 178, 190, 219, 232.

37. The Stran Trom- - A pale, yellowish maggot, closely resembling the Joint Worm, attacking the stalk in a similar munner, and changing to a four winged gnat.

'The eggs are latid on the stems or the forming heads of the young wheat, in the spring by wingless females, these hatching, produce a brood of winged female gats in June, which lay their iggs in or near the second joint from the head; the maggots from these eggs change to pupae in the fall and remain in the stubble and straw until spring, when the gnats emerge.*

This insect is a serious pest in some sections of the country, and doubtless occurs in West virginia.

For preventives, remedies, etc., see Nos. 173, 178, 219, 232.

38. The Wheat Saw Fly. ${ }^{2}$ A yellowish, milky-white worm, at out onc-half an inch long, mining in tho straw between and throngh the joints; changing to a shining black four-winged $\mathrm{Hy}$, banded and spotted with yellow.*

The eggs are depositer in the stalk just before the wheat begins to head. The young worm enter's the stalk and works its way down and through the straw, reaching the base below the first joint by the middle of July. It then cuts a circle from within, and just helow this point it makes its cocoon where it remains till spring. It then changes to a pupa and the adult emerges in May. 'The straws often break off whon the cut is made, and wheat thus aflected "lodges" bad!y."

This is a comparatively new wheat pest in this country, and probably occurs in West Virginia. A trouble resembling that caused by this insect was reported from Wirt county in 1890 .

For preventives, remedies, \&c., see Nos. 173, 181.

\section{Injury by the Young of Two-Winged Gnats}

Small maggots, causing young plants to be dwarfed and to change from dark green to yellow or brown, fail to head out or stalks shriveled at base and hend over or break off. See No. 39.

Slender maggots, mining in straw, causing the heads and upper joint to die and turn whitish. No. 40, 43.

39 The Messiun Fly Maggot". A small forotless maggot, abont 3-20 of an inch long when full grown; attackmg the young and giowitig wheat unver the slieath of the leaves near the lower joints of the stalk in the spring,

1. Isosoma tritici, Riley.

2. Cephns pygmoeus, Linn

3. Cecidornyia destructor. Say. *Compiled. 
and at the base of the young plants in the fall; causing an imperfect development of the straw and grain, or preventing the plant from developing a hrad; plants thus affected will be found upon examination to have either magents or objects like flax seed beneath the sheath from which a small, dusky, two wing. ed gnat emerges.

The eggs are deposited by the fly or gnat on the upper surface of the leaves near the salk in May or June. The young maggota make their .way down the outside of the straw beneath the leat sheath to one of the lower joints, usually the lowest one, where they station themselves and become imbeded in the soft part of the stem. Here they remain until fully matures, when they change to the flax seed stage,- the pupae,--and the flies soon emerging from these, deposit their eggs on volunteer wheat, oats, rye, etc., also in fall sown wheat and rye in September and Octoher; the earlier sown wheat usually being affeeted the worst. 'They pass the winter in the flax seed stage in the old straw and in volunteer and sown wheat, and the fly emerges in the spring.

This is a common wheat pest in West Virginia, often causing serious loss. 232.

For preventives, remedies, etc., see Nos. 173, 178, 185, 189, 219,

40. The Wheat Stem Maggot. ${ }^{1}$ - A whittish ar greenish worm or maggot, one-forrth of an inch long, mining in the stalks and causing the top to die; changing to a small two-winged fly.

The eggs are eleposited, in May and June, upon the stalk near the upper joint in which the worm burrows and develops causing the upper joint and head to die. 'The flies emerging from this brood in July, deposit eggs on the volunteer wheat and grass and one or two broods of fies develop, the last brood in time to deposit eggs on the young wheatia september and Uctober is when the maggots kill the central shoot and pass the winter in the stalk of the young plants, to appear as flies in the spring.

This was a common wheat pest in Monongalia and Preston counties, in 1895 , and doubtless occurs in other sections of the State.

For remedies, preventives, etc., seo No. 178, 187, 188, 219, 232.

41. The A erican Frit Fly Maggot. ${ }^{2}-$ Resembles and has similar habits to the preceding species.

For remedies, preventives, see No. 178, 187, 188, 219.

42. The Companion Fly Maggot ${ }^{3}$ - Similair to the two preceding species in form and habits, but much smaller.

All of the above, therefore, having similar habits, should have similar treatment. Seo No. 39.

\section{Injury by Thrips.}

Minute, slender insects, causing the same conditions as the three species mentioned above.

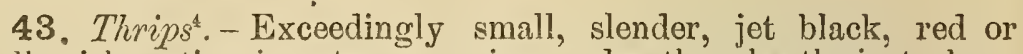
yellowish, active insects, occurring under the sheath just above

1. Meromyza americana. Fitch, ;

2. Uscis ls variabilis? Losw.

3. Oscinis sp(?)

4. Limothrips poaphagus(?) 
the base of the upper joint, where they suck the sub inance from the stalk and cance it tw wither and die; there is little differesece in the young and adults; common everywhere, but the damige by them is not, als a rule, serious.

\section{Injury by the Young of a Moth.}

A small worm horing in the stalk, cansing the top to die.

44. The Stull: Borrer.-(Seo No. 73) attacks wheat and other small grain, eausing the same white top appearance as mentioned ahove.

\section{Injury by Chinch Bugs and Plant Lice}

Small, dark or reddish striped bugs, or green plant lice covering the stalk and leaves and sucking the sap.

45. The Chinch Bugl. - Adult a blakk long, marked with white, one eighth of an inch long; young forms redclish, resembling iice. All stages suck the sap from the stalk and leaves and prevent the plant from developing.

The eggs are deposited lyy the adults, in the spring on, the roots of the young plants; they hatch in about two weeks into little red, louse-like bugs which feed at first on the roots and aiterwards on the stem, leaves and head. They reach maturity $m$ six or seven weeks and nigrate to other plants, often in enor. mous numbers, going from wheat to oats, corn and c ther plants.

This insect is an extremely destructive one, but fortunately has not proven to be very common in West Virginia, except in restricted localities. During tho summer of 1895 it did considerable damage in Grant and Hampshire counties, and I have been told that it occurred several year's ago in Mason county. 251.

For preventives, remedies, etc., see Nos. 171, 172, 173, 209, 222,

46. The Grain Louse,-(See No. 56,) also attacks the stalks of wheat and other grain; a common pest.

\section{Injury by the Young of a Moth and by Grasshoppers.}

47. The Arwy Worm.-See No. 14.

48. Grasshoppers and Locusts.-See Nos. 16, 17.

\section{Injury by the Young of a Beetle,}

A small grub living in the base of the stalk, causing the stalk to die and change to a whitish color which shows distinctly among the green plants.

1. Blissus leucopterus; Say. 
49. The Wheat Stem Grul-A small, wrinkly, whitish gruh, ahout one-halt inch long when full grown; boring in the top root and first joint above the root; the burrow packed with borings, killing the stalk after it bas formed a head; changing to a black snont beetle related to the plum curculio.

The eggs are denosited by the female beetle on the stalk near the surface of the ground, prob:thly in May, June and July. The young grub bores into the base of the stalk and roots, changing from one straw to amother. When full grown they change to a pupa in an edrthen cell in the soil and the adult appears in late summer ur clurmg tue fall, probably to pass the winter as an adult."

This insect was common in the spring of 1895 , in wheat fields in Monongalia conuty where it was quite a serious pest.

For remedies, preventives see No. 178.

\section{THE ERAVES.}

If leaves have a sickly appearanco and covered with small insects. see Nos. 50, 51.

If leaves are partly or wholly consumed or have a ragged appearance, see $\mathcal{N}$ o. 16, 17 .

50. The Green Plant Louse.--Seo No. 56.

51. The Chinch Bug.-See No. 45.

\section{Injury by Bugs and Flant Lice.}

THI HEADS.

Heals die prematurely and have a whitish appearance, conspicuout among the oreen ones; have a ragged appearance; grain fails to mature; or heads destroyed.

If white heads appear, see Nos. $39,40,41,42,43,49,44$.

If heads have a roughened appearance and the grain is shriveled, seo No. 52.

If covered with plant lice, see No. 56 .

If the grain is eaten ont and the chaff is foun $l$ on the ground, see No. 53.

If heads are cut off, see No. 57.

\section{Injury by the Young of Gnats.}

Kernels shrivelert; the hearts have a rongh and unnatural appearance, and with small, orange colored maggots on the inner surface of the chaff or milky grain.

1. Sphenophurus sp (paroulus Gyll.?)

* A similar insect obeerved in timothy bulbs from Kanawha and Monongalia counties in May 1896 . 
52. The Wherat Midge. - In orange yellow mageot from an eighth to a tenth of an inch long, absorbing the sulstance from the young kernel, causing them to shrivel and berome worthless; anlinlt, a mimnte grmat or mirlue.

The exware alepositerl by the midge in the crevices of the draff about the time the wheat is heading; the magents hatrhing from the exgs crawl within and feed mpon the flowers or milky juices of the kernel by absorption or sucking; when the magrots are matured they leave the hearls and enter the ground where they remain orer winter to appear as adults in the spring.

This insect was extremely comunon and destructive in West Virginia some twenty to thirty years ago, but of late years, it has not to our knowledge, done much damage.

For preventives, remedies, etu., see Nos. 170, 183, 184.

\section{Injury by the Young of a Moth and by Grasshoppers.}

Heads and young grain eaten by smooth, striped rorms, or by grasshopper's, and chaff scattered on the ground.

53. The Thite Itend Amm Wormi2. - When quite yourg a light colored worm with a black head, found feeding on the leares; at maturity it is striped with yellow and brown; about one inch long, and feed on the milky kernels of the heads.

The eggs are laid on the stem of the wheat in rows near the base of the leaves; the young worms hatch from the eggs in about five days, when they feed on the leaves, and when about half grown, attack the milkv kernels in the heard; they enter the ground or conceal themselves beneath rubbish to change to the chrysalis stage; the moths appear the following May.

This insect has not been observed by us or reported in West Virginia, but doubtless occurs in this State.

For preventives, remedies, etc., see Nos. 181, 182, 245.

54. The Angoumois Grain Moth. - The young feed on the grain in the field, see No. \$5.

\section{Preventive No. 188.}

55. The Wolf Moth ${ }^{3}$. - Similar to the above, but the worm spins a web over the grain and portions of the bead.

Prerentive No. 188.

Heads covered with small greenish lice.

56. The Grain Lonset. - A small, soft bodied, pear-shaped, greenish plant louse, sucking the vitality ont of the forming kernel;; causing them to shrivel; the young and some of the adult lice are wingless,. while part of the adults have wings.

The winged females deposit eggs on the young wheat in the fall; the eggs hatching in the spring into female lice, which suon give birth to living young,

1. Diplosis tritici, Kirby.

2. Leucania albilinea, Guen.

3. Timea granella, Linn.

4. Siphonophora avenal, Fab. 
each at the rate of five or six a day, and seventy-five to one hundred before they die. The soung commence to reproduce in a few days after they are born, and so on through the summer, increasing at an enormous rate if all the crnditions are favorable. They live on the blades and heads of wheat and other small grain until it is harvested, when they change to other similar plants and to the volunteer wheat, oats, elc., upon which they feed and breed nntil the young winter wheat appears in the fall. At this time a generation of winged malts and females appears, and the females deposit eggs on the winter wheat for the sprting brood.

This is an exceeedingly common insect in West Virginia, appearing at times and in certain sections in enormous numbers, causing serious damage to the wheat crop, and loss to the growers. It was reported from Marion, Mineral, Hampshire and Wood counties in 1890 and 1891, where it was unusually abundant.

For preventives, remedies, etc., seo Nos. 170, 246.

\section{Injury by the Young of a Swall Bee.}

Small worm mining in the straw causing it to break off just bslow the head.

5\%. The Wheat Head Pruner-1-A small worm resembling the wheat saw fly worm: the young of a four wingerl saw fly which we have termed the Wheat Head Pruner to distinguish it from its near relative, and on account of its habit of cutting off the upper joint of the straw, just below the kead, the worm living in lower portion of the stalk or straw. It did considerable damage in New Jersey and Pennsylvania in 1886 and 1887.

This insect has not been observed by us or reported in West Virginia, but there is no apparent reason why it should not occur in this State.

\section{STORID GRAIN.}

Stored grain damaged by having outer portions of the kernel eaten, or interior hollowed out; sometimes covered with webs rendering it worthless for ordinary use.

If the exterior of the kernel is gnawed and the inner portion partially or wholly consumed, without wobs, see No. 58.

If exterior is not gnawed, but interior consumed, with round holes in the kernels and some of the kernels are wobbed together, seo Nos. 60 a, 61.

\section{Injury by Beetles and Their Young.}

The kernels gnawed from the outside by the adults, and the young developing within the kernel.

1. (?) Dolerus sp. 
58. The Gramery Weevill-A small, brown and shining, flattenedsnout beetle, from an eighth to a sixteenth of an inch long. 'The hear is prolonged into a smout with which it punctures the kernels, and eats into the outer portion. The young form is a ninute, iootless grub.

The oggs re deposited in the punctures and the grubs hatching from thom feed upon the inner portion of the kernel where thoy transform to the beetle about six weeks from the time the eggs are rleposited. *

This insect often does immense damage to stored wheat, corn and other stored products in this country and Europe. It has not been observed or reported in West Virvinia, but doubtless occurs in this Stato.

For preventives, remedies, etc., see Nos. 190, 191, 216, 232.

59. The Rice Treerit? - A small, brownish snout beetle, onetenth to a sixteenth of an inch long, with four more or less distinct red spots on its wing covers; similar in of her respects and in habits to the preceding species, except that this species is a more greneral feeder, attacking rice and all of the smaller grains, the aclult often infesting cracker's and cakes.

It is a common insect in West Virginia, and especially injurious to corn and wheat that has been stored in one place more than one year.

For preventives, remedies, etc., see No. 190, 191, 192, 216, 232.

60. The Saw-Toothed Grain Beetle ${ }^{3}$-A slender flattened, reddish-brown heetle, one-tenth of an inch long, with six, saw-like teeth projections along each side of the middle portion of the body, (the thoras.) It feeds upon the outer portion of the kernels and the germ. The young is a minute, slender, active worm, ieoding on the outer and inner portion of the kernel and changing about from one kernel to another. A brood of this beetlo may develop every $2 \pm$ to 40 days.*

This is a common insect in West Virginia and is a general feeder, attacking all kinds of grain, kernels of nuts, candies, museum specimens, etc., and is a serious pest.

For preventives, remedies, etc., see Nos. 190, 191, 192, 216, 232.

\section{Injury by the Young of Moths.}

Interior of the grain consumed by small worms and the injury accompanied with webs.

60a. The Angoumouis Grain Moth Worm.-Attacking the grain in the field, in the shock, stack and granary. See No. S5.

1. Calandria granaria, Linn.

2. Calaudria oryza, Linn.

3. Silvanus surinamensis, Linn, *Compiled 
61. The Mediteranean Flour Moth Wrmm $m^{1}$ - A small caterpillar, or worm similar to the preceding, except that it is sparsely covered with long hairs. This is a serious pest, attacking grain and flour in mills in Canada and portions of New Liork.

This insect has not been ob-erved in West Virginia but millers should keep a sharp l sokout for it.

Its presence in mills may be known by the machinery becoming clogged with masses of flour and bran.

If this condition should occur in any of the flouring mils in the State the fact should be reported to the Experiment Station in order that we may assist in preventing the spread of the pest.

For preventives, remedies, etc., see Nos. 190, 191, 192, 216, 232.

\section{INDIAN CORN.}

\section{The Seed in the Ground.}

The corn fails to come up.

If the grain is hollowed out and the meal left about in the soil, see No. 6\%.

If the grain is gnawed from the outside, see Nos. 63,64 .

If holes are bored through the kernels, see Nos. $63,65,66$.

\section{Injury by Ants.}

62. Ants ${ }^{2}$-Two kinds of ants have been recorded as attacking and injuring the seed in the ground. As a rule, however, ants in the soll with the sprouting and growing seed indicate the presence of plant lice. See No. 71 .

\section{Injury by the Young of Beetles.}

Mining into and consuming the kernels.

63. Wire Worms. - Nine kinds of wire worms are said to attack the seed in the ground. See No. 2.

64. Two other kinds of worms ar'e noted by Forbes ${ }^{3}$ as injuring the seed in the ground, one ${ }^{t}$ of which is common in West Virginia, but is usually found in the bark of trees or feeding on sap, and is

1. Ephestia Kuehniella, Zell.

2. Solenopsis debıis, Mayr.

2. Myronica scabrinodis lobicornis, Nyl.

3. Forbes' 'th Rep't, Insects of 111 .

4. Ips fasciatus. 
supposed to be more beneficial than injurious. The other ono bas not heen observed ureported in West Virginia.

For remerlies and preventives see Nos. 208, 202.

\section{Injury by the Young of Flies or Gnats.}

Maggots mining into the grains, feeding upon the germs and inner substance after the kernels have becoure soft from laying in the ground.

65. The Seed Comn M/aygo ? $^{2}$ - -A whitish or yellowish maggot with lasger end dark, aloout or e-lourth of an inch long, changing to a fly resembling the loutere fly.

It has not been observed or reported in West Virginia, but doubtless ocenr's here.

For preventives, remedies, ete., see Nos. 176, 208, 195.

66. Bluck-hereded frowss Mrrggot". -A small, slender, white worm, one-tentls to one-fifth of an inch long, with jet black head; infesting the soft kernels and converting the inner substance into a paste-like substance, changing to a two winged gnat.

Cool, wet weather following corri planting, favors the attack of this insect; also stable manure in the bill would offer favorable conlitions for its presence.

'Ihere are numerous species of this class of insects, known as fungus gnats, but hive not been observer od reported as attacking corn in T'est Virginia. That they may do so in favorable seasons for their occurrence, there can be no loubt. I have observed similar worms in orange seeds, planted in tre greenhouse; and the po'ato scab gnat and other species of the same class were serionsly injurious to potatoes in the hill, in clillerent sections of the State, in 1891-2. See No. 87 .

For remedies, preventives, otc., see Nos. 20s, 176, 195.

\section{THE ROOTS.}

Young plants of a dwarfish appearance, in patches over the field, with the lower leaves of a yellowish or reddish hue, stop growing when about a foot bigh, or die.

If roots and base of stalk are e onsumed, see No. 67 .

If holes are bored into roots and base of the stalk, see No. 68 .

If some of the roots are dead, others decaying at the encls, or longitudinal, brown lines occur on the roots, see Nos. 69, 70.

1. Systena treniata.

2. Anthomzia Zeae, Rlley.

3. Sciara sp. 
If ants are observed around the plants and the roots are dead or shriveled, and small, bluish, soft-bodied insects covered with a whitish substance are found on or near the roots, see No. 71.

\section{Injury by the Young of Beetles.}

White, grubs or white worms consuming or mining into the central and smaller roots, or consuming and mining into the base of the stalk of young, growing corn.

67. The White Grubs. - These are serious enemies to the roots of corn, cutting off the main and lateral roots, and thus checking the growth of the plant, or killing it. For further description sce No. 1 .

68. The Wire Worme. - Are also destructive to the young corn mining in the roots and base of the stalk. For further description, etc., see No. 2.

69. The Northern Corn Root Worm. - A slender, white worm, twofifths of an inch long, with head and tail end yellowish brown; mining in roots of corn; consuming them or causing them to decay; the young of a small greenish beetle that feeds on the pollen of corn and other plants. The eggs are dwposited hy the beetle about the roots of cornstalks and stubble in the late summer or fall, and hatch the following spring, to attack the young corn if planted in the same land. 'The worms feed upon the roots until August, when they change to the pupae and shortly after the adult emerges.

This is a destructive peat in the North and West, but has not been observed or reported in West Virginia as doing damage to col'n.

For preventives, remedies, etc., see No. 178.

70. The Southern Corn Root Worm²-A small, slonder, whitish worm, somerwat larger than the preceding, mining and feeding upon the roots; the young of a common, small, yellowish green beetle, with twelve black spots on its back, found feeding on the leaves of plants; closely related to the striped cucumber beetle; life bistory not fully known.*

This is an excoedingly common insect in West Virginia, and the larvae doubtless do considerable damage to the roots of corn and other plants, while the adult is classed among our injurious, leafeating insects.

For preventives, remedy, otc., see No. 202.

\section{Injury by Plant Iice.}

Roots deadened or dwarfed without external injury. Eight kinds of plant lice are known to attack the roots of corn, of which

1. Diabrotica longicornis, Say. *Compiled.

2. Diabroti is 12-punctata, Oliv. 
the Corn Root Louse, No. 71 and the Grass Root Louse, No. 6, are especially injurious.

71. The Com Root Louse. ${ }^{1}$ - A surall, bluish green, pear shaperl, soitborlied insect, with a whitish rubstanes evering the bouly, and with mouth parts formeth for sncking, by which it pieres the roots and sucks ont the sap or liputds. 'Th" young forms and the alluts are winghess, except at brood that appeatrs in Maly.

The egrs of this plant lonse which are deposited on or near the old roots, in the fall are collected by the corm lonse ant" and taken to its nest where they are stored until suring, when the ants transier tle egass or young lice to the roots of smart weed and pigen grass and then to corn, and are there cared for and proterted by the ants. In return for this indispensable service the plant line furnish a cruantity of honey-like liynid from two tube-like project:ons on the hinder parts of their bodies upon which the ants feed. All the lice hatching trom the egus are females and they multiply at an enormous rate, each ie. male having young without the intervention of males, at the rate of about one Hery two or threc homrs, and the oflisprings, which are also females, commence having youm when they are a few days old. The ants transfer the lice from plant to plint to form new colonies. This process proceeds until fall, when the males appear and the last brood of females lay egas which are cared for by the ants, ats previously staterl.

Ti us, the ants contribute quite as much to the trouble as do the plant ifce thenselices.

'This insect and its benefactor, the ant, are coummon insects in prortions of Wrest Virginis, and in one section, near Ripley Landing, in Jackson county, they were found to be excoedingly common and destructive to curn, in May, 1891.

For preventives, romedies, ete., soe Nos. 170, 178, 196.

\section{THE STALK.}

Young plants suddenly disappear or wither, central shoots die or wilt; small burrows or punctures in the stalk; or they have sickly appearance and covered with minute insects.

If plants are cut off above or beneath the surface of the ground, aud tho leaves are drawn into the soil, see No. 72.

If young plants wither or are cut off, and upon close examination a web is found at the base of the stalk, see No. 72 ?

If the central shoot of young plants withers and dies and is easily pulled ont, or holes are bored into the stalk after they are nearly full grown soe No 73.

If young shoots are punctured before leaves unroll, and the leaves are filled with small holes, see No. 7t; if large holes, see No. so.

If the stalk has a diseased appearance, and is covered with small, greenish insects, see No. 76. If covered with minute, reddish and black insects, seo No. 75 .

\footnotetext{
1. A phis maidiradicis, Fabr.

* Lasius brunneus.
} 


\section{Injury by the Young of Moths.}

Portions or the whole of the plant consumed by worms that feed at night and remain in the soil through the day.

72. Cutworms. - These are among the worst enemies of the young growing corn. For further account of cut-worms see No. 7.

72a. Web Worms. - Living in a web at the base of the young stalks where it feeds upon and kills the plant. For further account of these insects, soe No. 8 .

73. The Stalk Borer. ${ }^{1}-\mathrm{A}$ dark colored worm, one to one and a quarter inches long, with three white lines on the back the full length of the body; on some examples the stripes occur on the front and rear third with the central poriton black or brown; boring into the stalk of young corn, and at different points in the older stalk, mining in the pith; the worm changes to a chrysalis in the stalk, or in the ground, from which a yellowish moth emerges.

The eggs are deposited on almost all kinds of plants early in April and May, and as soon as hatched the young worms bore into the young stalk. If the stalk proves to be too small to accommolate it, it migrates to a stalk, either of the same or some other kind of plant that is larger. I'ne worm changes to a clırysalis in its hurıow in the plant in July and August, or in the soil, the moth appearing in the fall, or po:sibly the following spring.

There is possibly several kinds of worms having this same habit of boring in the st ilks of plants, but so far only two have been recorded as attacking corn.

The stalk borer is a common insect in West Virginia and has been observed in corn and a great number of other plants. Small worms apparently of this same species are often found in the stalks of blue grass early in the spring, causing what is known as white top.

For preventives and remedies, see Nos. 171, 174, 230.

\section{Injury by Beetles.}

Young shoots punctured by a small beetlo before the leaves unroll. After they have unfolded they show numerous small holes.

74. The Sculptured Corn Curculio - -A dark colored snont beetle about three-tenths of an inch long; head and legs black; feet reddish, and with snout one-third the length of its body; mining into the young shoots; a serious pest in some sections of the country*.

Probably occurs in West Virginia, but has not been observed or reported.

For preventives, remedies, etc., see No. 171.

1. Gortyna nitela, Guen. *Complied.
2. Sphenophorus sculptilis, Uhlr.. 


\section{Injury by Plant Lice and Chinch Eugs.}

Plants showing an unhealthy eondition and stalks covered with reddlish and black bugs, or the stalk of the ear covered with greenish lice.

75. The Chimal Bug-Soe No. 45.

76 The Corm Aphid. - Dull green or redish lice covering the stalk that bears the ear; sucking the nourishment and proventing normal development of the grain, also occurring on the main stalk and the leaves.

For proventives, remedies, etc., see. Nos. 170, 178.

\section{THE LEAVES.}

Leaves partly or wholly consumer, or exhibiting a diseased condition.

If leaves are partly or wholly consimed, see Nos. $77,77 a, 77$.

If the leaves exhibit a diseased condition and are covered with minute. reddish and black stinking bugs, see No. 78 .

If corered with greenish or reddish plant lice, see No. 79.

77. The Army Worm,-not a common insect in West Virginia but liable to appear and do much damage, see No. 14 .

7\%u. The Locusts and Grosslopplers, - nos. 16, 17, When common these insects are quite injurious.

79b. Climbing Cutworms, - (see No. 7,) may do some damage by cutting ofl the leaves,

\section{Injury by Chinch Bugs and Plant Lice.}

Plants have a sickly appearance from the loss of sap extracted by the bugs and plant lice.

78. The Chinch Bug.-See No. 45.

79. The Com Aplis.-Plant lice, sucking the substance from the leaves, see No. 76.

\section{THE EAR.}

The growing ear injured, preventing perfect development, or causing diseased condition.

If the growing kernels are eaten and the burrowed spaces are filled with excrement, see Nos. 80, 81 . 83.

If stalks of ear and husks are covered with plant lice, see No. 82.

If covered with minute, reddishand black stinking bugs, see No

1. A phis maidis. 


\section{Injury by the Young of a Moth.}

Burrows between the husk and cob hy a worm; the young grains on the end of the ear eaten: the silk dead and the burrows filled with excrement.

80. The Corn Ear Worm.1-A pale green, or sometimes brownish worm, one to one and a quarter inches long when full grown; burrowing into the end of the ear and consuming the young grain; changing to a chrysalis in the ground and then to a moth.

The moth deposits her eggs on the silk of the forming eara; the young werms hatch from the egga and mine into the ear and feed upon the succulent kernels until they are fully developed; then they leave the ear and go into the ground, where they change to a chrysalis, remaining thus about two weeks, when the moth emerges. A brood of moths appear in the spring from the chrysalis that remainer in the soil over winter. There are probably three broorls of this insect in a single season. In the South, where cotton is grown, it is known as the Cotton Boll Worm.

This is a common insect in West Virginin and often does immense damage, especially to sweet corn. It also attacks young heans, peas, tomatoes, etc. In the spring of 1895 the moth appearer? before there were any ears forming, and it deposited it eggs on the central shoot of the young corn plants and the worms dia considerable damage by boring into and consuming the tender blades. The leaves that were not cut off by the worms showed rows of holes across them when they unfolied. It also was quite injurious to bunch bean and peas, see but the corn was was damaged very little by it that season.

For preventives, remedies, etc., seo Nos. 181, 178, 228.

\section{Injuxy by Beetles.}

The young kernels are consumed but the spaces are not filled with excrements, as is the case when the injury is caused by the corn worm.

81. The Indian Cetonia. -A brownish. hairy beetle, two thirds of an inch long by two fifths of an inch broal, head dark, wing covers yellowishbrown, with pearly and metallic tints; under side of the body black and hairy; emitivg a strong odor when liandled; resembling a bumbiebee when flying; appears early in the spring; common on flowers, and feeds upon young corn and ripe fruit. The young form is a white grub, but its life history has not been worked out.

It is a common insect in Vrest Virginia.

For preventives, rememedies, etc., see No. 228.

\section{Injury by Chinch Bugs and Plant Lice.}

82. The Chinch Bugs.-Attacking the stalk of the ear and the husk prevents perfect development of the ear, see Nos, 45, 76.

1. Hothis armiger, Hubn,

2. Fuphoria inda, Lind. 
83. The Com Aplik-Attacks tho stalk of tho oar and the husk and does somo damage. Its habits and life history are similar to that of other plant lice, ${ }^{*}$ seo No. 56.

\section{THE STORED GRAIN.}

Stored grain clamaged by having outer portions of the kernel caten, or interior bollowed out and somotimes covered with webs, rendering it worthless for ordinary use.

If the exterior of the kernel is gnawed and the inner portion partially or wholly consumed-without wobbs-see Nos. $83 a, b, c$ and $S t$.

If interior of kernel is wholly or partly consumed, with round holes in tho outer end, and the injury is attended with weh, see No. 85 .

\section{Injury by Beetles and their Young.}

Arlults gnawing the grain from the outside and the young dereloping within the kernel.

83a. The Gianmy Teerit.-See No. 56.

831. The Rice Treeril-See No. 59.

83c. The Saw-toothed Grain Beetle.-Soo No. 60.

84. The Cartelle -An oblong, lepressed, bark-brown beetle, about a third of an inch long. The young is a whitish, fleshy worm with a black or brown head, and dark spots in the three segments back of the head, and with two horny, curved projections on its tail end Both the ardult and the larvae feed on the grain,tho beetle feeding upon the outer portion and the larvae h.ollowing out the kernel, moving from one kernel to another along the cob, and finaly changing to a pupa in one of the kernels; the adult emerges throngh a large opening in the onter end. Corn infested by this insect has the appearance of having been eaten by mice. Some ears of corn infosterl by this insect and the saw-toothed grain bectle were sent th the Station by W. Harrison Pyles. Hebron, Pleasants county, IT. Va., who reported that considerable damage had been done to corn that had been kept over one year.

Remedios, Nos. 190, 191, 216.

\section{Injury by the Young of Moths.}

Character of injury similar to that of the Granary Weevil and Rice. Weevil, except that there are a few webs present, more or less adbering to the kernels.

*Complled.

1. Penebroides muritanious, Linn. 
85. The Angonmois Grain Moth. ${ }^{1}$ - The larva smooth, white worm with head and first segment of body brownisl ; abont twofifths inches long; feeding within the kernels and boring holes through the shells from which the moths escape. The adult resemble the common clothes moth.

The eggos are laid between the rows of kernels on the ear in the field or granary, and the young worms bore into the ker nel where they feed and develop in about three weeks to their full growth, then changing to the chrysalis, and the moth, the latter emerging in about 30 to 40 days after the eggs are depositerl.

This is a common insect in West Virginia and is a general feeder upon grain and other similar sul stances.

For preventives, remedies, etc., see Nos. 188, 190, 191, 216.

\section{THE POTATO.}

\section{THE PLANTED SEED TUBERS.}

The potato fails to come up, and if upon examination the eyes, or young sprouts, or the tuber has been eaten or is bollowed out, presenting a decayed appearance, it may be caused by insects.

If the surface is gnawed and the vital portions eaten away, see Nos. $85 a-b$.

If presenting a decayed appearance and without odor, or the interior portion worked into a pasie like substance, seo No. 86.

\section{Injury by the Young of Beetles.}

85a. White Gmbs.-(see No. 1,) may attack the seed tubers and damage them so they will fail to grow.

85b. Wire Torms. - (see No. 2,) may also do similar damage.

\section{Injury by the Young of Gnats.}

86. The Fungus Gnats, (seo No. 88) may do some damage. They at least breerl in seed tubers in the ground and are thus brought in contret with the growing tubers which they may attack and cause serious damage. See No. 55.

\section{THE GROWING AND IMATURED TUBERS IN THE HILL.}

Tubers injured or destroyed; injured by surface blemishes other than that caused by fungus scab; destroyed by having all or part of the tuber but the skin converted into a starchy, pasty or me lly substance, or a decayed condition not the result of dis eased germs.

If a small or large cavity occurs, partly or entirely covered by the thin skin of the tuber, or with portions of the skin projecting

1. Gelechia cerealella, $\mathrm{Ol}$. 
from the edges of the eavity, and the interior of tho carity when washod out shows asmonth, pitted surfice, or minuto, ilender, white worms with back heads aro found in the pits. Seo Nos. \$7, 88 .

If ordinary fungrus scab spots contain a whitish, mealy sub stance, and minute smouth, round bodied objects are common beneath, or in this subtance, see No. Sy; if white worms, sec No. 8T, 88.

If portions of the surface of the tuher is eaten away and the surfuce of the wound has a hoalthy appearance and shows minute tooth marks, see No. 90.

If round holes are bored into the skin and deep into the tuber, or entirely through it, seo No. 9l.

If the tubers bave the appearance if being affected by the rot disease, but are free from an unnatural odor and a paste like, or a mealy substance occurs within the skin, see Nos. 87, 88.

\section{Injury by the Young of Gnats.}

Minuté, whitish worms, with black heads, feeding in decayed spots in the tubers, also upon the healthy substance of the tuber.

87. The Potato Scab Gnat Form²-A minute, white, slender worm, one-sixth of an inch long; consuming the healthy substance of the tubers, causing one form of the potato scab, or a condition resembling rot; changing to a wingless female and a winged male gnat.

The eggs are deposited by the gnat on stored tubers in the cellar during the fall, winter and spring. The young worms enter the old scab spot= or slightly injured places, and under farorable conditions a brood is deve!oped every uwenty to twenty-fivedays. In the spring the gnats deposit their eggs in stable manure or other decaying vegetation, or on the seed potatoes and growing tubers in the hill to which they may have been transferred on the seed tubers or in regetable matter.

Here the young worms may attack the healthy skin of young tubers, but preferably where the skin has been in any manner slightly or seriously injured, or where scab spots are being formed by the scab fungus. Once within the tuber and the conditions remaining favorable the potato is destroyed by them, but if the worms are driven out by their natural enemies, or the soil becomes so dry that they disappear, the places infested by them will show nearly the same characters as the ordinary scab, and may be easily mistaken for it.

Favorable conditions for the occurrence of this insect in injurious, or destructive numbers, and for their attack upun potato tubers in the store room or in the soil are moist, warm cellars in which potatoes are stored, and prolonged, cool wet weather in the

1 Epidapus scabiei, Hopk. 
spring, summer or fall. They cannet exist, or at least thrive in ury soil or in a perfectly dry store room.

During the summer of 1891 and 1892 this insect and its near relatives, the funyus gnat worms, were especially common in Wood and Monongalia connties; and from personal study, observation and reports I am confident that immense loss of potatoes was cumsed by them during these yours, in different sections of the state. 'uthers received from Philadelphia contained great numwers of the insects, which is evidence that they were common in other sections of the conntry, as woll as in West Virginia.

It must be remembered that while the potato scab gnat worms caus forms of potatro scab, and may effect serious loss by extending injuries resuluing from other canses, they are by no means to hlamo for all kinds of potato scab, since it is woll established that a fungus discovered by Dr. Thaxter is the prin e cause of the commoner forms of the scab.

'The gnats may. however, under favorable conditions be morerlestructive than the fungus on account of their babit of penetrating deep into the substunce of the tuber, thus rendering it worthless.

For lreventives, iemedies, ete., see No. 170, 178, 176, 208, 194, 193.

83 The Funyus Guat Worms. ${ }^{1}$ - A number of worms, similar in general appearance to the potato scab gnat worms, but larger und both sexes of the alults have wings. The habits of all of the fungus gnat worms that infest the potato tubers are similur and the same general treatment answers for all.

\section{Injury by Mites.}

Small round bodied white objects in scab spots feeding on disoised or healthy substance of the tuber.

89. Mites. ${ }^{2}$ - Small, round bodied, eight-legged objects, related to spirlers, feeding in scab spots and extending the injury, but it anpears that they are not capable of causing a scab, and the injury carsed by them is not of a serious character. In fact, the presence of this little creature appear's to be disagreeable to the scab gnat worms, since they appear to be driven out by them when the mites become numerous.

\section{Injury by the Young of Beetles.}

Cavities gnawed in the outer substance by grubs, or holes bored into or through the tuber by worms.

90. White Grub Worms (See No. 1).- Often do considerable damage to growing potato tubers.

1. Sciena $\mathrm{sp.}$

2. Order Acarina. 
91. The Wire Horms (see No. 2) also attack and hore into potato tubers.

\section{THE STALKS.}

Stalks wilt and die; holes bored into them, or the inner portion is hollowed out.

If a small, whitish grub is fonud in the hurrows, see Nu. 92 : if holes are bored into the stalk or a black and white striped worm is found in the burrows, see No. 93.

If sta!ks are cut off near the ground, sce No. 94.

\section{Injury by the Young of a Beetle.}

92. The P'stato Stalk Bomer. ${ }^{1}$ - t whitish, logless grul, one-linth of an inch long when fully levelwped; mining in the stalk nuatr the ground, cansing the stalk to wilt; the arlult a 5 mall, grayish, snout beetle.

The female beetles lay their eggs in a slit marle for the purpose just above the surface of the grount. The exgs hatch in a few days and the worms boring into the heart of the stem mine downward towards the roots In a few weaks they change to the pupa within the stalk, and late in summer emerges as adults. In this stage the insect passes the winter in the stalk or any secluded place it can find. It also breeds in the stalk of various weeds.

This insect has not been observed or reported in West Virginia. For preventives, remerlies, etc., see Nos. 173. 230, 232.

\section{Injury by the Young of a Moth.}

93. The Stalk Borer.-(See No. 73.)-A black and white striped worm mining in the stalks.

94. Cutroorms.-(See No. 7.) - These insects were serious enemies to young potato plants in the spring of 1895 , especially in Jackson county, W. Va., where they kept the tops eut down over large fields.

\section{THE LEAVES.}

Leaves consumed; punctured with minute he les, or have a curled and sickly appearance.

If leaves are partly or wholly consumed and infested with reddish, soft, round-bodied insects and hard shelled, yellow and brown striped beetles, see No. 96.

If leaves have a ragged appearance, infested by long bodied, black or striped active beetles, see No. 97.

If infested by large green worms with long spine on their tail ends, see No. 100.

If leaves are punctured with small holes, or the surface eaten in spots, see No. 98.

1 Trichobaris trinotrata, say. 


\section{Injury by Beetles and their Young.}

Leaves partly or wholly consumed and the bare stalks left standing, see No. 61; or have i ragged appearance, seo No. 62; or punctured with small holes, see No. 63.

98. The Colorado Putato Beetle ${ }^{1}$-A thick-set, brown and yellow striped beetle, too familiar to every potato grower to need further description, as is the variegated red, soft bodied, humpbacked young frrm of this, one of the worst potato pests known.

As soon as the potato anpears in the spring the beetles lay their orange colored eggs in patches usually on the underside of the leaves. These hatch in about \& week into venetian red creatures that at once begin to devour the plant. As the young gruw they become lighter in color, and plainly show two ruws of spots on each side of the body. Keaching full growtn in two or three weeks, they leave the plant and burrow into the soil where they change to the pupx, thence to the adult. Ihoy now emerge from the ground and provide for another gentration, there being three or four during the year. the pest Liberuate as adults and pupæ.

For preventives, remedies, etc., see Nos. 229, 231, 202, 242, 245.

9\%. The Blister Becties. ${ }^{2}$ - Seven species of blister beetles are known to attack the potato leaves, but there are only three kinds that are especially common and destructive to potatoes in West viryinia, namely, the Pennsylvania Blister Beetle, ${ }^{3}$ a uniform black rpecies; the Ash Colored Blister Beetle, ${ }^{4}$ with a variety of the sume known as the Margined Blister Beetle. The third species is the Striped Bilister Beetle, ${ }^{5}$ which is yellowish with front part of the body marked with black and with two black stripes on the wing covers. All bave similar habits in teeding upon potato, beet, tomato and leaves of other garden plants, and are common on the flowers of the goldenrod and aster. They are very active in usiug their legs, but soldom resort to flight, although they have well developed wings. These inseets are widely distributed throughout the country and belong to the same ramily as the Spanish F'ly of Europe, in fact, derive their name from the blisters they cause when the liquids of their bodies come in contact with the skin of of the hands or other parts of the per'son.

The eggs of these insects are laid in the ground where the young remain feeding principally on grasshopper eggs, and it is only during the adult stage that they are injurious.

These are common insects in West Virginia and often prove serious pests, especially during the year following one in which grasshoppers or locusts were common.

Fur preventives, remodies, etc., see Nos. 202, 224.

\footnotetext{
1. Doryphora decemlineata, Say.

2. Nucncrous species belonging to the geaus (Lytta.) Epicauta.

3. H. Peunsylvanica.

4. E, cluera.

5. Eplcauta vittata
} 
98. Hea Beetles.-A number of species of flew bectles attack the potato leaves, all having somowhat similar habits. 'They aro small, black or brown beetles, varying in size from one-sixtuenth to one-eighth of an inch long, jumving like a flea whon disturbed.

The young mine in the leares or roots of clifferont plunts, but their life history is not well known

A black and small brown species are quite common on potato leaves in West Virginia, but as a rule, the damago is not very great.

For remedies, seo Nos 202, 207, 212.

99. Three Lined Leaf Beetie. ${ }^{1}$ - Young somowhat similar to that of the Colorado beetle, but coverer with a cloak composed of their excrements. The adult is a three lined beetle, resembling tho *ucumber beetle. It has not been rejorter from West Virginia.

For remedies, see Nos. 202, 228 .

\section{Injury by the Young of Moths.}

100. The Horn Worm². - A large green worm with a born on tail end; the adult is a large bodied moth common in West Virgmia, feeding upon the potato, tomato aud tobacco.

See also No. 167

102. Cutworms.-(See No. 7.)-Climbing cutworms may do considerable damage by eutting off the leaves at night.

\section{STORED TUBMRS.}

Tubers conrerted into a condition resembling decay.

103. The Potato Sab Gnat Worm.-See No. S7.

104. Fungus Gnat Worms.-See No. 88.

These insects often do serious damage when potatoes are stored in damp cellars, the trouble often being attributed to ordinary deeay or potato rot.

Preventive, a dry store room.

\section{SWEET POTATOES.}

\section{THE ROOTS AND TUBERS.}

Roots gnawed or mined.

\section{Injury by the Young of Beetles.}

105. The White Grubs,-(No. 1.) often attroks sweet potatoes and gnaws cavities in thom.

1 Lema trilineata Oliv

2 Phlegethontius (Sphins) celius.

*Compiled. oarolina. 
106. The Wire Worm,-(No. 2$)$ also attacks the tubers.

\section{TIE STAIR.}

Youn $y$ plants cut off at the surfuce of the ground at night, and consumed.

10\%. Cutworms.-(See No. 7.) The sweet potato plant is the farorite fool of certain kinds of cutworms, and they often do much damage and cause serious loss to sweet potato growers in West Virginia.

\section{THE LEAVES.}

Leaves have irregular holes eaten into them and completely riddled; surface eaten awgy in spots and strips.

If leaves have a ragged or riddled appearance with odd looking insects on them, (seo No. 108.)

If the surface of the leaves is eaten away in spots and strips, (see No. 109.)

\section{Injury by Beetles and Their Young.}

Leaves gnawfd and ragged, and on the underside odd looking insects of various sizes are found feeding.

108. Tertoise Beetles, ${ }^{1}$-The five different spocies of these small beetles. that attack the potato range from one-fourth to three-tenths of an inch in length; some species shining like gold, others with bright, metallic luster, and closely resembling a turtle in miniature. The young are broad and fitt, with many radiating spines and a forked tail which retains their cast off skin and excrement.

This tail forms a covering or parasol for the insect which is carried over the back.

'I he eggs are laid singly up $\mathrm{n}$ the leares and held in place by a sticky substance which the in-ect secretes. The larve feed almost exclusively on the under side of the leaves, and reach full growth in about three weeks, then they fasten the last two or three segments of the body to a leaf, and in a couple of days change to pupæ. In about a week the adult emerges. The winter is passed in the adult stage*

These insects are common in West Virginia, and are the worst enemies of the sweet potato, often causing much damage when this crop is grown.

For preventives, remedies, \&c., seo Nos. 202, 228, 236.

\section{Injury by Flea Beetles.}

Small flea beetles feeding upun the surface of the leaves.

1. Several species belonging to the genus Cassida.

*Compiled. 
109. The Flea Beetles.-(Seo No. 98.)-Quite a serions pest, feeding upon the surface of the lea es and often causing them to turn brown and dio.

(ommon at Morgantown within tho last few yers.

For preventives, remedies, etc, seo Nos. 202, 207, 236.

\section{ASPARAGUS.}

\section{THE STALKS AND LEAVES.}

Tender stalks with irregular, roundish spots eaten into them and the older plants defoliated or the bark eaten.

\section{Injury by the Adult and Young of a Beetle.}

110. The Asparaque Betle. ${ }^{1}$ - A pretty, red, vellow and shining blark insect, abont one.fourth of an inch in length; arlult with hearl black: thorax tawny red with two more or less distinct black spots on its crown; wing covers lemon-yellow and black, with orange margin; roung clull ash-grey or ohscure olive; head black, and jnst back of it two shining spots; legs black.

'This insect passes the winter in the adult state beneath bark, in crerices of woorl and other sheltered places. As soon as the spmaragns shows itself in the spring the beetles at once commence to feed upon it, and after pairing, deposit their eggs upon any portion of the shoots. In abont eight days the eggs hateh and the larve feel vigorously upon the outer surface of the young shoots and reach full growth in about twelve days. They then leave the plant, and beneath the surface of the ground or simply under the leaves. make a rlight cocoon in which they change to pupa, and ten days later the beetles emerge.

There are probaliby three or four brools a seasou the last brood feeding upon the bark and leaves of the oller plants.

This is an imported pest from Europe, and like other injurious insects that find their way to this country from foreign lands, is a serinus pest in some sections of the United States.

It has not heen observed or reported in West Virginia, but if it is not here, it will doubless soon appear wherever asparagus is grown in any considerable quantity. Therefore, asparagus growers should look out for it, and, if possible, prevent it from becoming permanently established.

For preventives, remedies, etc., see Nos. 215a, 234, 241.

\section{CABBAGE.}

Cauliflower, Kohl-Rahi, Kale, Rape, Brussels sprouts, Turnips, Rutabaga, Radish, Etc.

\section{THI ROOTS.}

Plants checked in their growth, turn blnish, or suddenly wilt under the hot sun.

If rootlets are burrowed along their surface and the main root is mined or girdled, see No. 111.

1 Crioceris asparagi, Linn. 
If the roots are cut off or eaten away, see No. 113a.

\section{Injury by the Young of Flies.}

Roots and base of stalk burrowed and containing whitish maggots.

111. Cabbage Maagots - White. cylindrical, footless maggots, about onethird of an inch long when full grown: living in the roots and stalk of cabbage and other nearly related plant; feeding upon the juices and seriously injuring and killing the plant; changing to two winged flies resembling somewhat honsefies, but smaller.

There are at least three kinds of these root or stalk boring maggots that attack the cabbage, turnip, raddlish, etc., one that attacks the onion, No $169 \mathrm{a}$ and another attacking tne corn, No. 55 .

The European Cabbage Maggot ${ }^{1}$,'is by far the worst enemy to the ronts of Cabbage. The following account of its life history applies also in a general way to the other species:

The flies appear in the spring about the time of setting cabbage plants. The egges are placed near the surface of the ground close to the stem. They hatch fn about a werk, and the larvæ feed for about three weeks when they. usually leave the roots and change to puparia in the soil near by. According to the different anthors the duration of this stage varies greatly,-from two weeks to three months.

There are probably three broods of this pest during the season, the second generation changing to the pupae in July. The winter is evidently passed as flies, pupæ and maggon - the last mentioned in the old cabbage roots, the purxe in the soil, and the flies in most any secluded place.

This is a very dostructive imported enemy with which the cabbage grower has to contend, and is widely distributed, occurring in nearly every State of the Union and the Provinces of Canada, doing much damage not, only to cabbage, but to other similar plants.

This and the radish maggot are quite common in West Virginia, but did not begin to attract much attention until the summer of 1890 and 1891, when the cabhage maggot proved quite destructive to cabbage plants along the Ohio Valley from Hancock to Wayne counties. But the radish maggot bas heen especially troublesome at Morgantown. for possibly seven or eight years.

For preventives, remedios, etc., see Nos. 173, 178, 197, $197 \mathrm{f}$ and 216.

112. Fungus Gnat Worms,-See Nos. 87 and 88 .

These black hearled worms were found quite common in turnips injurer by the cabhage maggot in 1894, and from what is known of their habits they may, in connection with this insect, prove a troublesome pest, especially in wet seasons.

\section{Injury by the Young of Beetles.}

Ruots cut off or injury similar to that caused by the cabbage maggot, affecting young plants.

1 Phorbia (Anthomyia) brassical, Bouch. 
113. Flea Bectles. - Young of these beetles are small, elongated, six legged worms, horing in the roots or leaves of cabbage and other plants, often doing considerable damage to young plants. Seu 117.

113a. White Grubs.-See No. 1.

\section{THE STALKS.}

Plants cut off near the surface or some distance above the ground, or have a stunted, sickly appearance.

If plants or roots are cut off, soo No. 114.

If they have a sickly appearance and the stalks are infested with maggots, see No. 116.

\section{Injury by the Young of Moths, Beetles and Elies.}

114. Cutworms. - The young of moths, (see No. 7) often cause serious damage to recently set out cabbage plants.

115. White Gruls.-The young of beetles, (see No. 1) sometimes cunsume the roots and a portion of the underground stalk

116. The Cabbage Jaggot, (No. 111), also infests the stalk above ground.

\section{THE LEAVES.}

Leaves partly consumed; filled with small holes, or young plants sudfenly disappear. Leaves on old plants curl upand have a sickly appearance or die.

If leaves on small plants are punctured with small holes, or the surface eaten off by minute, black insects with pale stripes, see No. 107.

If leaves are partially or wholly consumed and pale green worms are present, see Vos. 11s, 121, 122. If yellow and dark striped worms, see No. 119. If large black and yellow striped worms, see No. 123. If bluish transverse striped worms, see No. 120.

If leaves have a wilted, sickly appearance and large bugs with yellow and red spots are common, see No. 128.

If leaves are curled down and the under surface is infested with plant lice, see No. 125.

\section{Injury to Young Plants by Beetles.}

Upper surface of the first loares eaten by small pale striped beetle, causing them to wilt.

117. The Wary Striped Flea Beit $t^{1}-\mathrm{A}$ minute, shining, black beetle, one-tenth of an inch long, with two pale yellow, irregular stripes on the wing covers; feeding on the young leaves of cabbage and other related plants. The young live in the roots of the plants upon which the beetles feed.

1. Phyllotreta vittata. 
A common and serious pest in West Virginia

For preventives, remedies, etc., see No 202, 212, 212a, 2!2b, $215 \mathrm{a}, \mathrm{b}, \mathrm{c}, \mathrm{d}$.

\section{Injury by the Young of Butterflies and Moths.}

Leaves partly or wholly consumed and presenting a ragged appearance.

118. The Imported Cabbage Worm ${ }^{2}$ - A pale green worm, an inch or an inch and a quarter Ion $\cong$. feeding on the inner tender leaves of cabhage and other relater plants; changing to a common white hutterfly. Front wings of Butterfly white, with black tips and black spots; hind wings grayish white, with one or two dark spots on each.

The females deposit their egos nsually npon the upper surface of the leaves; these hatch in about a week and the larve feed vigorously. becriming full grown in alont two werks. They generally leave the plant and ind some shelterer nook where they change to the chrysalis stage, and in about ten days, dnring the summer, the butterflies emerge.

There are several broods during the season and the last one passes the winter in the chrysalis stage.

This is an exceedingly common cabbage pest in West Virginia, and causes serious less and much annor ance. 249.

For preventives, remedy, etc., see Nos. 197g, 202, 212 213, 245,

119. The Southern. Cullowge Wrom. ${ }^{3}$ - A greenish blue worm, somewhat over an inch in length when full grown : with longitudinal, yellow stripes. The young worms are yeliow with hlack hearls; a common cabbage pest before the importerl speries made its appearance. hut has been extremely rare since the advent of its foreign relative, until last fall when it appeared again. This worm changes to a butferfly similar to the imported species, but has more blacis marking on the wings."

The life history and habits are similar to that of the imported species.

For remedies, preventitives, etc., see Nos. 202, 245, 212.

120. The Purple Striped Cabbage Worm, or Cabbage Pionea. ${ }^{3}-$ A smaller worm than either of the preceding, with transverse stripes of white and purple across its back; head shining, greenish yellow; under side of hody pale green. It eats elongated oval holes in the leaves, gradually extending them until nothing but the larger veins remain; also bores into the heads: changing to a pupa in the ground, where it remains about twelve days, then changes to a pale, ochre-yellow moth with expanse of wings of about one inch.

2. Pieris rapae. schr.

3 Poutia (Pieris) protodice, Bolsd.

4 Evergestis rimosalis.

* Not compiled. 
This was an extremely destructive insect in the Ohio and Great Kanawha River valloys in 1890 to 1892 , being more common and destructivo than tho imported green worms, No. 11.8. A parasite similar to that mentioned under No. 247 was common in 1891 , but in many localities the hunches of small white cocoons containing the parasites were destroyed by grнrdeners who supposerl they were the eggs from which the wormis had hatched. It appears that this (abbuge pest has heen so completely subjugated by its parasite and by diseasos that : ince 1892 it has boen extromely rare.

For preventives, remedies, etc., see Nos. 202, 212, 213, $215 \mathrm{cl}$.

121. The Northern Cablage TTorm ${ }^{1}$--A light green worm, similar in appearance and hahits to that of the imported species, changing to a white butterfly.

'This insect is raro in West Virginia. With the exception of a number of sprecimens taken in the forest wilderness of Pocahontas connty, on Black Mountain, I have not seen it in the State.

122. The Cublurge Trom; Plusine - A pale green worm with paler Inngitndinal lines; feerling upon eahhage and other similar p'ants; changing to a moth that flies and deposits her egges at night; not a serions pest in West Virginia so tar as we have observed, but is quite a troublesome one farther south.

Remedy, same as for other cabbage worms.

123. The Zdhra Caterpillar. ${ }^{3}$-Black worms when young; feeding in clurters on the leaves. As they grow older they disperse and when full grown moasure nearly two inches in length, when it has redlish legs, and striped with velvet, black and yellow.

The adult is a moth. This caterpillar is anite destructive in somo sections of the country, but not a common insect in West Virginia at lea-t it has neither heen ob-erved nor reported from this state.

Remedy, same as for Cabbago Butterfly.

\section{Injury by Bugs and Plant Lice.}

Leaves infested with bugs sucking the liquids from the leaves causing them to wilt, turn yellow and die.

124. The Iarleruin Cubbage Bug or Calico Bach.'.-The adult is a gandily markod insect, being variagater with black, yellow and red. It is about five-ixteenths of an inch long by three-sixteenths of an inch broad ; the young resemble the adults except that they do not hare wings; they"feed upon the juices of the leares by means of their sucking mouth parts.

The insect passes the winter in the adult stage under all sorts of rubbish and

1. Pierıs oleracea, Boisd.

2. Plusia brassicae, Riley.

3. Msmestra picta, Harr.

4 Murgantia bistrionica, Eahn. 
about old cabbage stumps. In the early spring they le tve their winter quarters and lay their eggs on mustard or other similar plants. The eggs are placed in double rows on the under side of the leaves. On reaching maturity this brood migrates to the cabbage field where it at once commences its work of destruction and lays its eggs for another brood. There are several broods during the season.

This is a comparatively new pest in West Virginia, but is spreacling rapidly and is already a serious pest in certain cabbage growing sections. It appears that it originated in 'Texas from which it has gradually spread eastward and northward.

For preventitives, remedies, etc., see A os. 181. 172, 173, 218, $221,228$.

125. The Cabbage Plant Louse. ${ }^{1}-\mathrm{A}$ greenish, soft bodied, pear shaped insect, usually covered with a whitish suhstance, often occurring in great numbers on the leaves, causing them to curl up and have a dirty, sickly appearance. It also attacks the leaves of all other plants nearly related to the cahbage. For the life bistory of plant lice see No. 56 . 243.

For pi eventitives, remedies, etc., see No. 170, 209, 212, 212a, 245,

\section{CUCUMBERS.}

\section{Melons, Squashes, Pumpkins.}

\section{THE ROOTS.}

Plants fail to come up; young plants cut off or suddenly wilt and die; old plants suddenly die or have a dirty, sickly appearance.

If plants fail to come up, see Nos. 126, 127, 128.

\section{Injury by the Young and Adults of Beetles.}

Plants fail to come up and grub worms or wire worms are present; plants wilt and die; bark is eaten off, and striped beetles are present or small, white worms in the roots.

126. White Grubs.-(see No. 1.) Cutting the roots off.

12\%. Wire Worms (see No. 2.) Boring into the roots.

128. The Striped Cucumber Beutle and its Young (see No. 134.) Adult feeding upon the bark of the main root; the young mining into the roots, causing the plant to wilt and die.

\section{THE STALKS.}

Young stalks cut off by worms; bark eaten off by striped beetles; sap sucked out by bugs; stalk mined by a white worm.

1 A phis brussicx. 
If young plants are cut ofl. See No $129 \%$.

If young plants suddenly wilt and die and the surface of the leaves and stalks is eaten. See Nos. 130-13t.

If old plants wilt and dio. Seo No. 187.

If the leavos and vine wilt and the stalk of the vine is mined by a white worm, soe No, 129. If not mined and covered with bugs. sce Nos. $131-132$.

If covered with lice, see No. 133.

If the base of the stalk is mined by minute, white worms, see No. 130.

\section{Injury by the Young of a Moth.}

A whito worm mining the stalk or vino.

129. The Squash Vine Borer. ${ }^{1}$ - A whitish worm about one inch long when full grown, with brownish head; boring into the pith of the vines, cansing them to wilt and clie; changing to a pretty moth, with front wings olive brown, and hinder ones transparent, and with orange colored body, spotted with black.

The female inoths lay their eggs upon the stem of the plants near the ground and the eggs hatching, the young mine into and feed upon the succulent interior. By the latter part of summer the larvae have reached full growth, and, leaving the vines, make cocoons in the soil where they change to the pupae and remain in that stafie until spring.

This insect is becoming a common pest in West Virginia,

For preventives, remedies, \&c, see Nus. 172, 180, 181, 230, 232.

129a. Cut Worms, see No. 7 .

\section{Injury by Beetles and their Young.}

The surface of the young stalk and old vines eaten by striped beetles, and the base of the stalk mined by minute, white wor'ms.

130 The Striped Cucumber Beetle.--(See No. 134.) Adult feeding upon the young stalks and the bark of the vine; the young mine in the base of the stalk.

\section{Injury by Bugs and Plant Lice.}

Sucking the sap from the stalk and vine; large black or small grayish bugs and green plant lice.

131. The Squash Bug.-(See No. 137.) Adult and young sucking the sap from vine, causing it to wilt.

132. The False Chinch Bug.-(See No. 139.) Adults suck the sap from the tender shoots.

133 Plant Lice.-(See 128.) Sucking the sap from the tender shoots.

1. Mellittia ecto. Westiw. 


\section{THE LEAVES.}

Surface of leaves eaten by striped and small black beetles; sap sucked from leaves or older by black and grayish stink bugs, or greenish plant lice.

If young plants suddenly wilt from heing eaten, see No. 134 . 136.

If surface of young and old leaves are eaten, seo Nos. 134, 135,

If plants have a sickly, dirty appearance, and the leaves are covered with plant lice, see No. 138.

If covered with stink bugs, see No. 137.

If the tip of the vines are infesterl with -mall, grayish bigi that suddenly disappear when disturbed, see No. 139.

\section{Injury by Beetles and Their Young.}

Leares of young and old plants eaten by striped and spotted beetles and the leaves mined by small, white worms.

134. The Striped Cucumber Beetle. ${ }^{1}$ - A yellow beetle about onefourth of an inch long, with two black stripes on each wing cover and a black head; feeding upon the surface of the leaves, vine, bare of stalk and roots, killing or seriously injuring the plant. The young, or larva, is a small, slender, white worm, about one third of an inch long and the thickness of a pin, with head and tail black.

The adult makes its appearance early in the season, even before the vines are through the ground, and immediately begins its work by entering the soil through eracks made by the young plants as they are pushing their way out into the sunlight, and deposits its eggs on the roots and also feeds on the tender plantlet. As the plants grow the beetles continue to feed and leposit eggs, but, by perseverance and proper nursing, the vines are ke $t$ alive until they appear to be strong enough to withstand the attack of the heetle. At this time the insects also seem to diminish in numbers and the trouble is apparently over, when the vines suddenly begin to wilt, which, usually, is due to the larvae that have hatched from the eggs laid by the beetles, and mining into the roots. The larvae reach finll growth in about four weeks, when they leave the roots and make little cells in the soil near by, and in about three weeks later emerge as beetles.

The winter is passed in the adult stage under old rubbish and other secluded places, from which the pest emerges in early spring and is ready for its work of destruction as mentioned above.

Thereare two or more broods of this insect; the late brood feed. ing upon the leaves and the bark of the vine and roots; also upon the young fruits. It often occurs in immense numbers on immature melons, pumpkins, etc., late in the fall. This appears to be a common and destructive vine pest wherever the cucumber and its nearly related plants are grown.

1. Dirbrotica vittata, Fabr. 
For preventives, remedies, ete., see Nos. 198, 2121 .

135. The Tirelie Spotted Cucrumber lieetle. ${ }^{1}$ - A beetle nearly related to the striped species and of about the same size, but with black spots on each wing covers in place of the two stripes. It also has similar hubits of feeding on the leaves and breeding in the roots, but being a more general feeder on the leaves and roots of various other plants; it is not nearly so destructivo to the cucumber family of plants as the striperl species. The young of this insect is a sorions corn pest. Sou No. 70. L'reventives and remedies the sime as for the striped species.

136 The Cucumluer Hen Beetle: - A small, black flea like beotle, ahout one-tenth of an inch long, with yellow antenna and legs, feoring upon the surface of the teaves.

'The young is a slender', whitish worm, mining in the leaves of the vines and possibly of other plants."

'This is an extremely common insect in Wost Virginia, attacking the leaves of potutoes, tomatoes, and many other kinds of plants, as well as these of the cucamber family.

For remedies and preventives, ete., see Nos. 202, 212b, 207, 204.

\section{Injury by Bugs and Plant Lice.}

The sap sucked from the leares by large black or small grayish stink bugs and green plant lice, cansing the leares to wilt or turn yellow and clie.

137. The Squash Bug. ${ }^{3}$ - Adult a flattened stink bug, about onehalf an inch long, of a rusty, black color on the back, and the under sicle of its body yellowish; emitting a very repulsive odor when crushed. The young, which are called nymphs, are of various sizes from minute, louse like creatures to the size of the adult; of a grayish color and resembling the adults, except that they are wingless when quite young; they feed in elusters on the leaves by sucking the juices.

The eggs ure deposited from late spring until fall in clusters on the under side of the leaves. In a few days the eggs hatch and the young bugs congregate in clusters to feed on the sap, and thus remain until about half grown, when they scatter about over the plant. The adults pass the winter under boards, leaves, rubbish, or anything that aftords protection.

- This is a common vine pest in certain sections of the State and often eauses serious loss to grower's of squashes, mellons, cucumbers, etc.

For preventives, remedies, etc, see Nos. 171, 181, 218, 229.

1 Diabrotica 12-punctata, Oliv.

2 Crepidodera cucumeris, Harr.

3. Anasa tristis.

*Compiled. 
138. The Melon Plant Louse, ${ }^{1-A}$ greenish black, soft bollied insect, infesting the under surface of the leaves of cncmubers, melons etc., sucking the sap from them; causing the inforter leaves and rines to have a dirty, sickly appearance. This plant lonse, in general habits and life history, resembles other plant lice, see No. 56.

For preventives, remedies, etc., see Nos. $17($ ', $215 c, 212,212 \mathrm{l}$, $216,245,242,243$.

139. The False Cinch Bug. ${ }^{2}$ - Adult a grayish brown stink bug resembling the chinch bug somewhat, in form and habits, but does not show the contrasting black and white colors of the latter. It infests the tender leaves and the terminal shoots of the vine, check ing its growth and causing a diseased condition.

The young are louselike, wingless creatures, resembling somewhat the adults

This was an exceedingly common insect on musk-melon vines in market gardens near Morgantown during the summer of 1895, where it dir serious damage. It also attrcks other plants.

For preventives, remedies, etc., see No. 171, 209, 2126

\section{The Fruit.}

Holes bored into the green fruit by worms. See No. 140, 141.

140. The Pickle Torm. ${ }^{3}$ - A yellowish white worm, about an inch long when full grown, with transverse rows of shining spots on each segment; boring into the y oung fruits and rendering them worthless. A yellowish brown moth; the front wings with dull, golden yellow markings, and the inner two thirds of the hind wings of the same color.

The eggs are deposited by the moth in June or July. The worms begin to appear about the middle of July in this latitude, and continue their destructive work until September. They bore holes into the fruit and feed upon the fleshy part. Reaching maturity in three or four weeks, they foreake the fruit, and craw together a portion of the leaf that is near or on the ground and there in make their cocoons of white silk. Here they soon change to a brown chrysalis and if not too late in the season, emerge as a moth in about ten days. If late, they remain in their cocoons until spring.

This insect is widely distributed over the country, but has not been observed by us or reported in West Virginia.

For remedies, preventives, etc., see No. 232.

141. The Melon Worm ${ }^{4}$ - A yellowish green worm, attacking both the young melons and the leaves, changing to a beautiful moth with glistening white wings, bordered with black.

This insect has not been observed by us in this state, but it is said to be quite a serious pest further South.

For preventions, remedies, etc, see No. 232.

1. Aphis ououmberis, Forb.

2. Nysius destructor, Riley.
3. Fudioptls nitidalis, Cramer. \$, Eudioptis hyalinato, L. 


\section{TOMATO AND EGG PLANT.}

\section{The Stalk.}

Plants cut of ne:tr the surface of the gromul, or sudidenly wilt. If the plant is cut alf. sere No. 14 ti.

If the plant suddenly wilts, a hole is bored in the stalk, and a brown and white struped worm is found mining in the heart of the stem, see No. 14\%.

\section{Injury by the Young of Moths.}

142. The Stull Borer-(seo No. 73). This worm often attacks the stalks of trmitoes.

146. Cut Wrmm-(see No. 7 ). These insects are often serious enemies of tomato plants.

\section{The Leaves.}

Plants defoliated ; lo:res partly consumed ; leares punctured by small holes or the surface eaten.

If the entire leaf, leaf stalk and a part of the tender branches are consumed, seo No. $14 \%$.

If leaves are cut ofi at night, see No. 148.

If plants are defoliated or the foliage presents a ragged appoarance, see No. 143 .

If small light colored spots occur on the surface of the leaves, or numerous small holes are eaten into them, see No. 150.

\section{Injury by the Young of IMoths.}

Leares and leaf stalks eaten or leaves cut off by worms.

147. The Ifom. Horm. See No. 100. This insect is often a serions enemy of tomato plants.

For preventives, remedies, etc., seo No. 228, $2 t 8$.

148. The Climbing Cutworms. (Seo No. 7.) Cutworms often climb the plant at night and foed upon the leaf stalks and tender shoots; cutting the leares off, which are found on the grount in the morning.

\section{Injury by Beetles.}

Plants defoliated; the leares present a ragged appoarance ; punctured with small holes or the surface eaten.

149. The Blister Beetles.-(See No. 97.) These insects are often destructive to tomatoes and egg-plants.

150. Flea Beetle.-(see No. 168.) A small brown and black 
species, one-sixteenth of an inch long, is very injurious to young and old tomato and egg plants, eating the surface of the leaf or puncturing it with numerous holes, causing it to have a whitish, sickly appearunco.

They have been common and quite troublesome pesis in the Experiment Station gardons for the last few years.

For preventives, remedies, etc., see No. 203, 204, 207, 212, 212 .

\section{The Fruit.}

Holes bored into the green fruit resulting in decay.

151. The Corn Ear Worm. - (See No. So.) This worm also bores into the green fruit of tomatoes and is sometimes a serious pest.

Preventives, remedies, etc., see No. 232.

\section{BEANS.}

\section{The Seed in the Ground.}

If planted seed fails to germinate and it is not the fault of poor seed, it may be due to injury by ants No. 152, grub worms No. 1, wire worms No. 2, fungus gnats No. 88, etc., although very little observation has been made to determine the extent of the damage cansed by those insects.

\section{Injury by Ants.}

152. Ants. - These insects have been observed feeding upon lima beans just before and after they germinate. The inner portion including the germ was hollowed out and the mealy portion seattered over the ground near the infested seed.

Remody No. 196.

\section{The Stalk and teaves.}

Plants cut off, or wither and die; stalk or vine and leaves covered with lico; leaves eaten.

If plants aro cut off at night, see No 153 .

If plant or vine withers and suddenly dies, see Nos. 154-155.

If plants have a dirty and sickly appearance, seo No. 156.

\section{Injury by the Young of Moths.}

Plants cut off ; stalks mined; or leaves cut ofl by worms.

153. Cutworms, (See No. 7.)-These insects often do serious dumage to young bean plants by cutting them ofit, and some damage to old plants by sevoring the leaves and tender shoots. 
173. Strilk Borer.-(See No. 73.)

155. The Beren. Time Bure. - A new pest resombling the squash borer; observer in Woorl connty in July. 1893, whero considerable damnge was done. My attention was called to it by Mrs. Bumford Neal. It is a whitish worn about one inch long, resembling very closely the Symush liorer, No. 129. Attacking pole lina bean vines usually at a point two or three feet above the ground. liomedy No. 230.

\section{Injury by Plant Lice.}

Plants of a dirty, sickly appearance and covered with lice.

156. The Pean Plant Louse."-Similar in appearance and habits to other plant lice. See Nos. $56,135$.

\section{The Green Pods.}

Holes bored into the green pods and the contents consumed.

157. The Cum Eir Worm.-(See No. 80.) - This insect did considerable damage in Monongalia county to green beans and peas in the spring of 1895, attacking the pols of bunch, corn or pole and lima beans, rendering them worthless for use.

\section{Injury by a Beetle and Its Young.}

If beans are found to have numerous holes in them and the inner substance converted into a powder, see No. 158 .

158. The Bean ITevil. ${ }^{3}$ - A small, brownish beetlo abont oneeighth of an inch long, with wing covers shorter than the body; the young, a small, whitish, footless grub, infests the bean, destroying tho germ and rendering it worthless for seed.

The eggs are deposited ly the female beetle on the pods of the growing beans, and the young grubs hatching from them mine into the growing seed within, where they remain, feerting but little during the summer, but in the fall and winter they consume the inner substance anil soon change to the nupa and then to the beetle which bores ont through the skin, often leaving it full of holes. The beetles may also deposit eggs npon stored beans and the young enter the dry seeds and produce in this manner several generations.

From one to fifteen grubs may occur in a single hean.

This is an extremely common pest in West Virginia, and doubtless occurs in all parts of the State, since we have received it from many widely separated sections

See preventives, remedies, etc., see Nos. 213, 214, 216.

\footnotetext{
1. Sesiid sp?

3. Hruchus obsoletus, say.

2. $A p b$ is $s p$.
} 
Peas.

The same insects that attack the bean may attack the pea, except the reevil attacking the stored peas.

159. The l'en Weevil. ${ }^{1}$ - A small, brownish beetle, three eightbs to one-fourth of an inch long, marked with a few white spots on the wing covers ; otherwise resembling the bean weevil ; the young is also similar in appearance and habits to that of the bean weevil, except that but one grub occupies a single pea and the germ is not disturbed; since buggy peas will, as a rule, grow when planted, hut will not make as vigorous, healthy plants as will those that are not infester. 'The pea weevil also differs from the bean weevil in not developing a second brood in the stored peas.

Remedies, Mreventives, etc., see No. 213, 214, 216.

\section{CELERY.}

\section{PARSNIPG, PARSLEY, CARAWAY, ETC.}

\section{The Leaves.}

Leaves partly or wholly consumed, wilt, appear sickly, or full of smill holes.

If leaves are caten and balls of cxcrement are found under the plant. or the leaves have a ragged appearance, seo Nos. 160, 161.

If the outer leaves wilt and clroop, and small black bugs occur at the base of the leaflets, see No. 162 .

If the leaves have a dirty, sickly appearance and are covered witb plant lice, see No 163.

\section{Injury by the Young of a Butterfiy and a Moth.}

Leaves of a ragged appearance infested with worms.

160. The Celery Caterpillar. ${ }^{2}-\mathrm{A}$ larva with trangverse marking of yellow and black, about $1 \frac{1}{2}$ inches long; when disturbed they thrust out a pair of organs or horns just back of their heads that enit an offensive odor. Infest the leaves of celery, parsnips, etc, chrnge to a black, swallow tailed butterfly marked with yellow.

The butterfly doposits her eggs on the under side of the leaves. The larva hatching from these ogos feed on the loaves till full grown, when they leave the plant, and in some secluded place change to a chrysalis and in abont ten days or two weeks the perfect iusect appears.

This is a common pest in West Virginia, but seldom seriously injurions.

For preventives, remedies, etc., see No. 228.

1. Bruchus pisi Linn. 
161. The Zetra Cuterpillur.-(Seo No. 128). Tuis insect attacks the celery as well as cablage.

\section{Injury by Bugs and Plant íice.}

The extremity of the leaf and the first two leatlets drooping and wilterl; later second prir of lentlets aflerted and at the basu of the stem eluster of small black bugs oceur. *

162. Tegro Bug. - Arlult a small, black insect, whout one-eighth of an inch long by one-twelfth broad; foeding in clusters at the junction of tho leatlets with tho main stalk. 'The young similar to the adult.

A common insect in West Virginia on weeds or other plants and is the insect usually to blame for the disugreablo buggy taste of berries. -

This insect has been seriously injurious to celery in Michigan and other sectious.

163. The Celery Plunt Lomse. ${ }^{2-}$-Similar in general appearance, habits and life history to the cabbage and other plant lice. See No. 125.

\section{TOBACCO.}

\section{The Roots.}

The young plant fails to grow, wilt and die.

\section{Injury by the Young of Beetles.}

The roots or the baso of the stalk eaten, or the main root mined.

164. White Grubs.-See No. 1.

165. Wire Worms.--See No. 2.

\section{The Stalk.}

Stalks cut off near the ground.

166. Cutworms.-(See No. 7.) These insects sometimes do serious damage to young tobaceo plants. 


\section{The Leaves.}

Portions of the leares consumed, also filled with holes or the surface eaten in spots.

If leaves are parily or wholly consumed and lurge balls of excrements occur under the plants, see No. 167.

If holes are eaten into the leaves, see No, 168 .

\section{Injury by the Young of a Moth.}

Portions of the leaves consumed by large groen worms.

167. The Zobacco Worm, or Ilorn Worm. ${ }^{1}$ - A large, green worm about three inches long when full grown, with a horn on its tail and obliquestripes on its sides. This worm changes to a large moth common among Jamestown or Jimson weed blossoms.

The eggs are laid in the srring and the larvae hatching therefrom feed until about the last of August when thry have reached full growth. At this time they burrow into the soil and soon change to brown pupae with a jug like handle appendage. In this stage they remain until spring when the moths emerge.

This, and nearly related species, are common inserts in West Virginia, the worms also infesting tomato and other similar plants.

liemerly, etc., seo No. 228-248.

\section{Injury by Beetles.}

Small holes eaten in the surface or through the leaves.

168. Flea Beetle."-Small, brownish beetles infesting the leaves and jumping like fleas when disturbed.

I his is a common 1obacco pest and quite often causes serious damage to the leaves. It canses, however, what is known as spotted wrapper tobaceo, which is considered ormumental for cigars, and is in demand on this account. This condition is causer when spots are eaten in the surface and do not extend through the leif. The damage. however, to the tobacco by this insect doubtless excet d's any benefit that may be derived from the mottled condition.

For preventives, remedies, etc., see No. 212.

\section{Dry Leaves and Manufactured Products.}

Dry leaves eaten full of holes and tobacco dust scattered about, throigh or beneath them where they are stored; cigars and cigarfttes with small holes in them.

1 Ph'rgethontius Caro'ina.

2 Epitrix parvula, lab 
Injury by the Beetles and Their Young.

Charucter of injury as above.

169. The Cigarette Berth. - I small, brown beetle three-sixteenths of an inch long, feoling on tolnaco, anyome pepper amb medicinal roots; often ciusing serions damago to stored and manufactured tobaceo.

'T'his insect is common in Mlorgantown and doubtloss in other' sections of the Strte. There tro also other species of bectlos nearly related to the Cigmette Beetle that feed upon dried tomaceo.

For preventives, remedies, etc., see No. 232.

\section{ONIONS.}

\section{The Roots or Bulbs.}

Leaves wilted, lying prostrate on the ground and perhaps turned yellow.

\section{Injury by the Young of a Fly.}

The base of the young plant or the bulb mined by a maggot.

169a. The Onion Maggot. ${ }^{2}-\mathrm{A}$ white maggot, about one-third of an inch long, tapering to a point from the hind end which is thick and blunt, with suall, tooth-like projections. It changes to a fly similar to a cabbage maggot fly to which it is nearly related and bas a similar life bistory.* See No. 111.

This is a widely distributed insect, und although we have not seen it in West Virginia, it doubtless occurs in some localities.

For preventives, remedies, etc., see No. 197f, $213,216$.

1697. Cut Torms. (No. 7) are also serions enemies of the onion.

\section{TUETHODS OF COMBATTING INSECT PESTS.}

\section{Preventives.}

Preventives and precautionary methods of dealing with insect pests are of prime importance, and every one who suffer's losses in any way from the presence of insects on cultivated plants, should study this phase of thesubject thoroughly, and thus endeavor to avoid the necessity of the proverbial pound of cure.

1. Lasioderma serricorne, Fab.

2. Phorbia (anthomyı) ceparum, Meig. *Compiled. 


\section{High Culture and Clean Farming.}

In dealing with the insects of the farm there is nothing, perhaps, that will contribute so much, generally sparing. ts exemption from serious insect depredations as will bigh culture and clean furming.

1\%0. IJealtiy Plants.-It is a well known fact that vigorons, healthy growing plants are far less liable to attark. and are fnr more likely to recover from injury, than those that are in any way weakened in vitality from lack of fertility or neglect Ther efore, if the farmer and gardener gives special attention to the fertility and drain age of his land, procures the hest seed and hy pioper planting and cultivation secures vigorous plants from the start. and by proper care endeavors to keep them in this condition until the product is matured, he will have accomplished more in preventing loss from insect depredatione than ho would accomplish by the best remedies known applied to half-starved, neglected plants.

Healthv, vigorous plant: will seldom be attacked or serionsly injured by Plant Iire. such as the Corn Root Lonse, Grass Root Lonse, Wheat Midge, Cabbage Louse; White Grub, Wire-worm, Stalk Borer, \&e.

Weak plants are a menace to healthy ones, since they are atracked by plant lice and other insects, and thus form a nucleus from which invasions may start that will result in the destruction of the healthy plants, except when the natural enemies of the injurious insects are common when such plants may exert a beneficial influence. See No. 246.

171. Clean farming and gardening is also of especial importance in preventing tho multiplication of pests, by depriving them of hreeding and hiding ylaces. Especially is this so with reference to those insect enemies of cultivated plants which breed in weeds of various kinds, and those that pass the winter in dead stalks, stubble, weeds, etc. Clean farms and gardens will offer unfavorable ronditions for Cut-uomms. Stalk Borers, Chinch Buq. Marlequin Cabbage Bug, Cabbage Maggots, Joint Worms, tho Hessian Fly, and all other insects that breed in the stalks of small grain or pass the winter in the old stalks and stubble. Among the most important methods in this line are the following:

172. Destruction by fire, feeding to logs or other stock all infected plants or fruit, surplus vegetables, rublish and waste matorials.

173. Destruction by Fire, or othemvise, of the stubble, stalks anr straw of crops that have been badly infested by insect pests, provided the parasites of the insects are not common. See No. 246. 
These methods are important to prevont and destroy Cut-rorm.s,

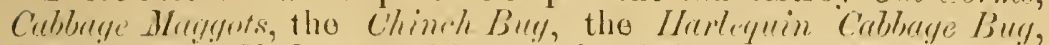
the loturo stult: Burer and in ects that infost the stalks of wheat.

174. The Destmuction of groming weeds to prevent the breeding of tho cermon Stulk Burer", C'lover Stem Borer, ate.

\section{Fertilization.}

Under this heal much can be accomplished in the prevention of loss from insect ravages, both in the securing of vigorous plants and in tho influcneo of the fertilizer material upon the insects.

175. Stable, Jornyard and vegetulde home made menures are of :urantage in preventing loss from some insects, yet they may contribute to firvorable conditions for the increase of others. Stable manure applied to sod land and plowed under for corn has been found alviutageous on land bally infested with white grubs and wire corms. On the other hand stable manures applied in corn and potato hills or drills may result in serions damage from the

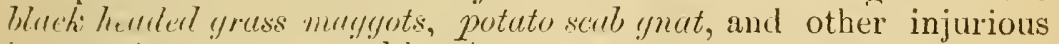
insects that are attracted by the manure.

176. Inimit and other potash fertilizers, as well as those containing a lawge per cent of phosphoric acid and nitrogen have been recommenled by entomologists and others as valuable preventives and remedies ayainst insert attack.

Ashes may also be used to ardvantage both as an insecticide and a fertilizer, dusted on the leaves of plants and placed around the root

177. Tubacco, dust and stems, is a valuable insecticide, and these waste products are worth all and more than they cost as a fertilizer, when dusted on the leaves and placed around the plants.

\section{General Farm and Garden Management.}

In efforts to control and prevent insect depredations much depeuds upon general management. Neglect and bad management will contribute to the rapid multiplication of insect pests and to the losses from their depredations, while the opposite will contribute to the diminution of the pests and to the adrancement of the profits on the products.

178. Rotation of Crops.-Annual plants should be grown in the soil as far removed from that in which they were grown the previous year as possible. and the same class of plants should not he grown in the same land oftener than every other year, or if posible, not oftener than every three years. Perennial plants, such as grass, clorer, etc., should not occupy the soil after they cease to yield a profitable return. When they begin to fail from 
injury to the roots by insects or from other causes much benefit will result from planting the lands to cultivated crops one or two yerrs, followed by small grain before seeding to grass aguin.

Rotation of crops offers unfavorablo conditions for grub womns, wire worms, northern corn root worm. com and grass root alhidl., com ear wom, wheat straw morm, Hessian Fly, and other insects infesting growing wheat, cabbage, nnion and curn.

\section{Thime of Plowing.}

180. Summer Plmoing - When it is desired to reseed meadows and pastures without planting to any other crop, the land should be plowed in June or July, and again in August, then seeded to mixed grasses. This will destroy many insects and prevent cutworm moths, the adults of wire worms, grub woms and other de. structive insects from depositing oggs. Mearlow lands plowed and reseeded in this iuanner every three year's have been found to yield bountiful crops and to be reasonably free from insect attack.

181. Fall Ploning.-To destroy young cut-worms and prevent the moth from depositing egos in land intended for spring crops, also to destroy or drive out other insect- such as the white grmb and wire wom pupae, army wom, com ear worn, harlerquin cabbagebug chinch biug, etc.

182. Winter Plowing.-To destroy pupae of grub worns, wire worms and other insects as above.

183. Deep Plowing.-To destroy the wheat san" H.y, wheat midge, etc.

\section{Time and Method of Planting.}

184. Early Planting of Wheat and early varieties to prevent the attack of the Wheat Midge.

185. Late Planting of wheat, cucumbers, molons, etc., to prevent the attack of the Hessian Aly on wheat, striped cucumber beetle on cucumbers, and striped thec beetle on cabbage.

186. Growing Plants in Large Quentities. - This methorl has been found to prevent serious injury from cabbage worms, and douhtless will do the same with many other insects since it gives the parasites and other enemies an opportunity to breed and keep the injurious kinds in check. There are also other advantages in growing large quantities of certain vegetables and plants which makes this an important one to consider.

\section{Harvesting:}

187. Farly harwesting to destroy the clover seed midge and prevent its attack on the second crop. 
188. Farly threslieng to prevent the attark on wheat grain by the $.1 n$. fumuis amin moth, wolf moth, etc., and to destroy the wheat stem maggot.

189. I'tasturing xtrck on carly sown wheat in the sprring to destroy the /lex.rin $t ! \%$ I ato pasturing clorer to prevent the attack and destroy the aloricesed mirige.

190. Removal of infester protucts, as far as possible from the growing crops or storer products that are liable to be infesterl. This refers to the removal of havestal small gran infested byany of the sträw inhabiting insect, as well as grain infested with gruin mollh and weerils; also clover hay infested with tho clorer hay worm.

191. Clean Mones and Girmaries. Removal from barn mows and stacks of all old hay infested with the domer liay worme, and small grain infested with grmin wer vils, before the fresh product is stored. All grain sbonld bo removed from granaries and if pests are present, thoroughly fumigate with bysulphide of carbon before new grain is stored in them.

192. Feeding surplus in fested and refuse products to stock. - All surplus and refuse vegetable pro ncts infested by insects or those that are liable to becomo so, should be ferl to hogs or other stock ; and all clover hay should be fed or otherwise disposed of before the new crop is barvested.

193. Sturving Out.-If a given plant or set of plants are so badly infested with insects that it is no longer profitable to grow them, a general abandonment of their growth for a fow years will serve to starve out the insects. Cultivation of infested soil during the summer to keep down all vegetation will starve out many insects and prevent others from depositing eggs.

194. Erempted Locrlitics. - It is sometimes found that from elevation, soil, and climatic conditions or from other unknown causes, some localities are totally exempt from certain insect pests. This in the case of the rose hug, fungus gnats, wire worms, grasshoppers. blister beetles, a al many other insects is due largely to soil conditions. This is an important subject regarding which comparatively little is known. Hence, the importance of our readers making a study of it and of our correspondents notifying us of the occurrence or non-oceurrence of the different pests in their respective localities.

195. Drainage is a preventive against wire worms, meadow maggots, black-headed grass maggots, fungus gnats and scab ginats.

196. Destruction of ant.' nests is a preventive against corn root lice and other plant lice fostered by ants. Nests or colonies of 
ants may be easily destroyed with bi-sulphide of carbon, or boiling hot water poured into a hole made with a stick or a piece of round sharpened iron bar. Their nests may be located by follow. ing their line of march to and from their feeding ground. (See also poisoned bait, No. 41.)

\section{Repellents.}

19\%. a. Terosene; $b$. turpentine; c. coal tar; $d$. carbolic acid and like substances are sometimes used in connection with sand, sawdust and like material plac d around or near plants to repel insects by the strong odor.

$19 \gamma_{e}$. Naphthaline, placed with stored grain, beans, etc., will tend to prevent the attack of weevils.

197. $f$. Paroffine Oil is also used to destroy and prevent the attack of the onion maggot.

197 $g$. Tunsy Tea is somptimes usel on cabbage to prevent the attack or drive away cabbage worms as well as the butterfly that deposits the eggs.

197h. Salt.-A small quantity pla ed around young plants of various kinds is said to be a succesoful remedy against cutworms, the corn web worm and white yrubs.

\section{Fencing Out.}

198. Thin cheese cloth, muslin and wire netting placed over cucumber and other plants to keep out insect pests until the plants have become sufficiently strong to resist the attack. Striped cucumber beetles, striped flea beetles on cabbage, hlister beetles and many other insects may be fencer out in this manner.

199. Paper and metal bands placed around the stalks of young plants will prevent the attack of cutwomns. This is al-o a successful method of preventing the attack of other insects having similar babits.

200. Boards coated with coal tar to fence out chinch bugs, traveling cut worms, etc. Is said to be a successful fencing out method.

201. Coal tar and like substances poured on the ground around plats and fields against chinch bugs, traveling cutworms, armg worms, \&ic.

\section{REMEDIES.}

Ansenites.

203. Paris Green (poison).--A well known and common remedy for almost all kinds of insects that bite anci consume the leaves 
of plints. There are two kinds of this insecticide, one areto arsenitr " "enp?", which is the common green substance; the other,

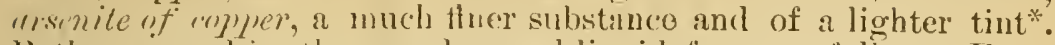
both are used in the powder and liquid form as follows: For a spray use one promol of the poim to 150 to 200 gallons of water. When used dry it is mixed with flour, loar dust. plaster or conl ashes. 'To 10 llss. of flour' or 20 lbs. of any of the other substances, add $1 \mathrm{lh}$. of the poison and mix. This is clusted on the plants by placing a quantity of it in a muslin bag which is attached to the end of a stick and the dust distributed by striking tho bag with another stick. It i also applied with powder bellows and powder gun. 'T he liquid is ap lied with a wisp sprinkler or some form of force pump. See Bulletin 21 and 43 of this station for de. scription of apparatus for applying insecticides.

204. London Purple (Poison).-Similar to Paris Green and is used in the same manner.--It is cheaper but more liable to injure the foliage.

205. White Arsenio (Poison) is sometimes recommended as an insecticirle, but since it injures foliage worse, and is more dangerous to handle, it is selilom used.

206. Arsenite of Lerrl, (Poison) $\uparrow$ a new insecticide, a combination of arsenite of soda and acetate of lead, mixed as follows:

11 ounces acetate of leal

t ounces arsenate of soda

100 gallons of water

2 quarts glucose or molasses.

The same proportions as above may be userl for smaller quantities. It is applied in the usual way. it does not injure the foliage.

207. Arsenates and Copper Sulphate, (Porson.) - A combined insecticirle and fungicide-Paris Green, London Purple, etc.,-mixed with blue ritriol and lime, as follows:

Dissolve 6 lbs. copper sulphate (blue vitriol) in a wooden oì earthen ressel; in another vessel acld tr 4 lbs. of fresh lime enough water to reduce it to the consistency of a thick whitewash. Pour this slowly into the coppor sulphate solution, strained through a course sack stretehed across the top of the vessel. Dilute to 45 gatlons before using, and add 2 ounces Paris Green or London Purple.

208. Compsive Sublimate (Prism.) - At the rate of 23 ounces of corrosive sublimate to 1.5 gallons of water is used to soak potato and other seed before planting as a preventire against the attack of insects and diseases of plants.

\section{Contact Remeaiies.}

The remedies that kill by coming in contact with the body and

\footnotetext{
"Ment oned first by the Division of Entomology, U. S. Dept. Agr, through Mr. C. L. Marlatt ju I"isect lifh, Vol VII., ph. tiss-til.

+ Introduced by the Gipsy Huth inm. nf Massachusetts.
} 
breathing pores are used against insects, which, owing to their feerling habits, crnnot be killed with poisons, such as trot bugs and plant lice that feed upon the juice; of planis by sucking it out; also yrain and seed infesting insects in granaries, etc., which can be reached only with deadly gasses.

209. Tierosene Einulsion is one of the hest contract remedies known for the destruction of plant bugs and plant lice. It is prepared and applied as follows: In 1 galion of boiling water dissolve, thoroughly, $\frac{1}{2} \mathrm{lb}$. hard, soft, or whale oil soap; while this is very hot add 2 gals. of kerosene, and at once commence to churn the whole mass with a syringe or force pump, "rawing the solution int? the syringe or pump and for cing it back into the vessel. Continue this until the whole mass assumes a creanv appearance and will adhere to the sides of the dish instead of gilining off like oil. This is the stock or standard emulsion, and must always be diluted before using; to what extent depends upon the class of insects to be treated; usually dilute with abont 12 parts of water.

210. Potash Snap. - Concentrated lye $1 \mathrm{lb}$; cotton seer oil 3 pints.; soft water 3 gals. Poil the lye in water mntil dissolved, then add the oil and boil two hours. replacing evaporated water with hot water from time to time. Use $1 \mathrm{ll}$. of this mixture to 8 or 10 gals of water for plant lice or to 1 gallon of water for scale insects, \&c.

211. Whale Oil Soap. -Concentrated lye $1 \mathrm{lb}$.; whale oil 3 pinta; soft water $3 q^{\text {ts. }}$; directions same as above.

212. Pyrethrum Insect P'owder.-A vegetal)le substance ground into a tine powder, which is, when fresh and pure, a valuable insecticide. It may be diluted as follows:

Pure powder 1 part, wheat flour 10 to 20 parts; allow it to stand in a tight vessel for a few lays before using. Apply with powder gun or bellows to cabbage to kill cabbage worms, flea buttes, etc. It may also be used in a liquid form, which is prepared by stirring one table-spoonful in two gallons of boiling water, and use with a sprayer as soon as the liquid is cool enongh.

212 $\alpha$. Tobacco in various forms is a valuable in-ecticide. It serves as a preventive and repellent, a poison and a contact remedy.

212b. Tozacco Dust is a cheap waste product valuable to destroy plant lice and prevent the attack of the striped cucumber beetle, flea beetles, etc.

212c. Tobacto Stems are valuablo to place around plants, serving as a mulch and a repellent against insect attack.

212d. Liquid made by hoiling stems or dust in water to form a strong decoction, which is applierl with a sprayer. 
ishes in the land intended for cabbage and other relaterl plants. The trap rrop is started early and allowed to grow until thoromghly inf-sted with the

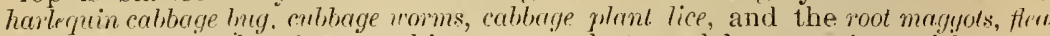
beetles, ete., then the plant and insects are destroyed by spraying with pu: e kerosene oil or boiling hot water.

219. Trap $C r^{2} 0 p$ for wheat infecting incects, especially those inf-sting the young plants, a strip of wheat is sown farly along one side of the fielıl intended for wheat. Then, just before sowing, plow the trap crop under, or destroy it hy cultivation durng a hot, dry day.

220. The squash borer, squash bugs and nther insects may be trapped and destroyed in a similar manner by starting a few plants eally for the especial benefit of the insect.

221. Trapping Ender Boards, Leaves and Bunches of Grase Cutworms, the harlequin cabloage bug, the squash bng; etr., may be attracted to bunches of grass, cabbage leaves, boards, etc:, laid on the ground near the infested plants, under which the insects will seek shelter, and may be easily collected and destroyed early each morning.

222 Ditching against army woms, chinch bugs, grasshoppers. When there pests are threatening a crop, it may sometimes be protected by a ditch surronuling it, into which the insects fall and may then be burned by the aid of straw s'attered in the ditches, or if water can be run into the ditch, a small amount of kerosene or petroleum on the surface will accomplish the desired result.

223. Hopperdozer-A long shallow pan containing co 1 tar or kerosene, hack of which is a screon, pulled by a horse o ver a badily infested field. This mothod is extensively used in the west where it is elaimed to be one of the best methods of destroying the young of the Rocky Mountain locusts. The insects jump into the pan and are killed by the tar or oil.

224. Windrows of Straw placed along the edge of a field into which blister beetles may be drawn and then burned.

\section{Baiting.}

225. Poisoned Bait.-Clover, grass and any early vegetation cut and tied in small bundles, then dipped into strong Paris green water and scattered over the ground jurt before the plants are set out is an excellent methor for destroying cut-worms. Poisoned wheat bran is also used for this purpose, placed near the plants that are to be protected. Sweetened poisoned baits might also be used to destroy aphid-protecting ants.

226. $T r(t)$ Crops of vegetables and plants also can be utilized for this purpose by spraying them with the poison.

227. Potatoes cut and stuck on the end of a stick and placed in the ground where wire worms are common is said to be a gond wav to trap these insects. When they collect on the potato they are lifted out by means of the stick and destroyed. 


\section{Hand Piclring.}

229. Adults, egys and lamae, collectod by hand when they first appear, is often one of the best methoks to prevent future fumble. especially when there aro only a fow phats to protect, and it maly frequently pay on a lorge scale if cheap labor' can ho had. 'This method is nsed against the followne insects: white grubs collecter

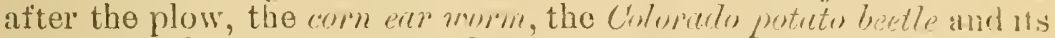

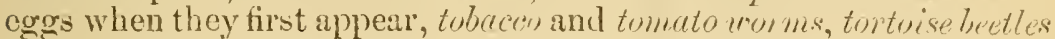
and young on sweet potato vines, first adults of the aspuragus beetle, the celery caterpillars and tho first (abbnge butterflies ap)pearing in the spring, which nuay bo caught with insect nets by children.

230. Digging Out or Cutting Out.-Cutumms aro dug out from around recently injured plants, and wet woms and com worms collected in tho samo manner. Stalk borers, squash and bean rine borers may bo cut out without injuring the plant if they are detected soon after they enter the rino.

231. Jaming and Beating. - Tho Colorarto potato beetle and its young may be collected by beating them off the vines into a pan containing a small quantity of water and kerosene. This is a method that is extensively adopted in kitchen gardens and by persons who object to using poison insecticides.

232. Destruction of Infested Plants and Fruit is an important and simple method of destroying many insects, such as the sculptured com curculio, stalk borers and tho cabbage maggot, the potato stalk borer during the growing season and after digging the potatoes by burning the infested vines; the destruction of vines infested with the sqaash borer; pickles and melons infested with the pickle worms, and volunteer wheat to destroy the Hessian fly and other insects with similar habits.

\section{NATURAL ENEMIES.}

\section{Domestic Animals.}

233. Hogs are serviceable in rooting out and destroying white grubs and other insects in sod land just before plowing for a crop. Many waste surplus and infested vegotables may be profitably fed to hogs and at the same time materially lessens the number of insect pests.

234. Poultry destroys immenso numbers of insects and may be profitably employed against certain pests such as the asparagus beetle, grasshoppers, cutroorms and many other insects. 
235. Turieys are especially fond of grcsehoppers, and a flock of them on a farm, will render valuable service against these pests.

236. Toung clickiens cooped up in the garden will destroy immense numbers of striped cucumber beetles, flea beet'es and other smaller insects

237. Other Live Stock may son etimes be used to advantage to eat down early sown wheat and thus destroy the Hessian fly and other insects that attack the young stalks of wheat; also to keep down rolunteer grain in stublible land and to consume surplus feed, such as clover, otc., to prevent its being kept over.

\section{Wild Animals.}

238. Among the wild animals there are numerous insect destroyers.

239. Sliuntes are among the most valuable in destroying white grubs, since they search for and dig great numbers of them out of the ground. They also feed upon other insect.

240. Tuads are great insect destroyers and may posiibly be utilized to an advantage in gardens.

211. Birls consume immense numbers of insects, but make no choice between injurious and beneficial ones.

\section{Beneficial Insects.}

There are almost if not quite as many beneficial kinds of insects as there are injurious ones, consisting of predaceous insects, which attack and devour insect pests; and parasitic insects, which breed in the living bodies of other ins . cts, and thus cause their final death.

242. Predaceous Insects.-Among the beneficial insects of this class are lady birds, ground beetles, Tristle flies, (tachina flies, ) soldier bugs, etc.

243. Lady Birds or Lady Beetles are among the best friends of the farmer, destroying, as they do, immense numbers of plant lice and insect eggs. They are small, broad-bodied beetles, usually red or yellow, with black spots on their wing covers. Their young are small, blackish, long, soft-bodied creatures which are also ravenous feoders upon plant lice. When these insects are abundant, in company with plant lice, care should be taken not to destroy them.

244. Ground Beetles.-Black, blue and green shining beetles of various sizes, from very small to an inch or more in length, in- 
cluding a great many different kinds; found in the ground under stones und boards, rumning aromind on the surface of the ground, or climbing plants. Some of this class of predaceous insects, both in thoir adult and young forms, aro great insect ilestroyers, some of which attack the white grut. mire womms and cutwor s. Others attack the eggs and young of the crimerulo potute lyetle, the latter being a small, blue-backed bectlo with a reddish head and thorax.

245. Pircasitic Insects.-This class of insects includes many hundreds of forms that are among the farmer's and gardener's hest friends. The majority of them are minute, four-winged gnats, whilo other's are small, wasp-like insects with long stings, or two winged thies, resembling the common honse fly, but usually larger and the body corered with stifi, spiny hairs.

The principal ones with which the farmer and gardener should be sufficiently familiar to readily recognize and protect, as his hest allies in combatting insect pests, may bo mentioned as follows:

246. Parasites of Plant Lice.-It may be safely said that plant lice would be among the very worst insect enemies of plants were it not for their numerous predaceons and parasitic enemies. Bofore applying a remedy to lestroy the lice, therefore, it shonld be ascertained whether or not these natural enemies are present, and if sn, at least a few infested plants should be left to breed the parasites, and if the parasites are very common, it will, in some cases, be best not to attempt to destroy the lice by artificial means, since by so doing more harm than good may be done.

The presence of plant lice parasites may be known by the in. flated brownish appearance of some of the lice clinging to the infested plant. On close examination they will be found to be dead, and many of them with round holes in their backs from which minute, wasp-like parasites hare emergod. Theso parasites often appear in great numbers, and if left alone will often practically exterminate the lice. The wheat crop is often saved from serious injury if not total destruction, nearly every year by the attack of theso parasites on the grain aphids.

An experiment conducted by us in tho greenhouse at the Experiment Station with one of this class of parasites proved that they can be utilized to great advantage in controlling plant lice in the green house.

247. Parasites of the Cabbage Worms.-Bunches of small whitish or yellow silken cocoons are often found attached to cabhage leares infested with cabbage worms. These should be carefully protected since the insects emerging from them are the cabbage growers best friends. They deposit their eggs in the body of the worm; the eggs hatch into minute maggots which soon become 
full grown and emerge through the skin of the worm to make their little cucoons either on the back of the worm or the leaf. A great many worms are thus destroyer and if the cocoons are protected, invaluable service will he rendered hy the parasites. There is another parasite that attacks the chrysalis of the cabbage butterfly, as many as fifty or sixty of them developing within a single chrysalis.

248. Parasites of Cuterpillers. - An enormous number of caterpillars like the toba:co worm and potato worm are destroyed by large two-winged flies, which deposit their whitish shining eggs upon the backs of the worms near the head; the egys hatch into magoots which enter and develop within the body of their host, and after the worm dies, the maggots chango to smooth brown, egg-like iorms, from which the flies emerge. There are a great many kinds of these flies, and they not only attack all kinds of soft bodied catterpillar's, but also attack the young of the Colorado potato beetle, grasshoppers, etc. 'Therefore, if catterpillars and other insects that are collected by hand are examined and all full grown ones that have eggs on them are left on the plants to breed the friendly flies. much good will be accomplished towards reducing the number of this class of pests.

Tobacco and other worms are also frequently found covered with small, white cocuons, similar to those of the cabbage worm parasite. All worms thus infested should be left on the plant until the parasite emerges.

\section{Diseases of Insect.}

249. Insects are often attacked by diseases which within a very short time will apparently ex terminate all the individuals of a species.

250. Clover Leaf Beetle Disense.-The most striking example of this is found in the disease that attacks the clover leaf beetle. Early in May the clover will be found covered with small, green worms that threaten to destroy every vestige of this valued plant in an entire county, but almost invariably a disease appears among them before they have done serious dimage, and within a day or two scarcely a living worm can be found. The diseaso comes like a blighting wind, sweeping over the entire infested area, possibly of thousands of square miles. A fow escape, however, to lay their eggs for another brood. Were it not for this disease, it would be impossible to grow clover in the regions infested by the clover leaf beếle.

251. Chinch Bug Disease.-The chinch bug is at times attacked by a disease which destroys the bugs over large areas, within a short time. This disease is 
being utilized by Entomologists and farmers in Kansas, Minnesota and Illinois, to keep the drearlal chinch bug nniter control. Diseased bugs are distriburel over a field infected b hoalthy hiars, and if tho conditions are favorat lo ithe healthy huss take the disadsoind die. The artificial introdnction of the sick buen is not always smecessful, but sullieient snecess has been attainerl in the States mentioned, to demonstrate the possibilntiss of this method of combatting certain insect pests that are susecetible to this am like discases:

252. In a linlletin just received from the Kentuk kx Experiment station, Prof. Gorman gives an aceount of some mineresting resnlts whth the chinch bu: disease transfered to cutworms, showing that these pests can to a certain extent be killed by it.

252a. Grasshoppers are also attacked hy a similar disease, and those dying with it may often bo scen clinging to stalks of grass, weeds, ete.

253. The White Grul, is attacked by a peculiar fungus disease which in its final stage of development sonds out two growths from near the beal of the grul, which may extend sererul inches throngh the soil mntil the upper ends reach the open air, when the spores are formed to spread the disease to the other grulss.

254. The Cubbage Worm and a number of other insect pests aro often attacked by diseases, and many of the young forms are thus destroyed.

These diseases are being studied by specialists in several of the experiment stations with a view to utilizing them, by artificial inoculation and transfer from one locality to another, as a means of controlling certain serious pests. Rapid progress is being made in the knorvledge of this subject, some encouraging results have already been obtained.

\section{Caution.}

Beneficial animals, insects and diseases attack and destroy enormons numrers of injurinus insects. Soms injurions kinds, likn the clover leaf beetle, the army worm and plant lice which, if unmolested by their enemies, are capable of terrible depredations -are thus often kert in complete subjugation. Parasites and diseases may be introduced to chock the ravages of certain insect peste, but it will not do, however, to place too much confidence in these friendly elements of the farmer and gardener, or to even hope that they will, under natural conditions or artificial control, accomplish in every case all that is necessary. At best they can on $y$ be considered as valuable aids or allies in our warfare against the inscet enemies of plants, to be protected. encouraged and utilized as best we cnn, remeiubering that in order for an insect enemy of a plant to furnish food for friendly insects, animals, etc., it muet itself have food. Thus the plant may be destroyed or ruined before our friendly allies appear. 
Some Prime Requisites for Success, in Dealing with Insect Pests.

Fertility of the soil; thorough cultivation; healthy, vigorous plants; clean farms and gardens; and rotation of crops are the primerequisites for preventing serious injury to cultivated plants by insect pests.

In combatting injurious insects the prime requisites for success are a general knowledge of the insect enemies and friends of plants; their habits and the character of their attack; the selection of the proper remedy and its promptand thorough application upon the first appearance of the enemy; also the prot ction and encouragement of all friendly animals, inserts and diseases that will aid in the future suljugation and control of the pests.

Among the requisites for success in preventing the spread of new or strange pests is the sending of specimens of the insect or its work to the Fxperiment State Entomologist for identitication, with a request for information upon the best known methods of combatting it.

\section{Instructions for Sending Specimens by Mail.}

If possible, specimens of insects or their work, or both, should always accompany letters of inquiry about insects.

Specimens of dead or living in sects may be sent by mail in tin or wooden boxes. quills, hollow pieces of wood, or small vials, packed in cotton. The postage on the package will cost one cent for e ich ounce or fraction thereof. Specimons of insect work may be enclosed in the letter or in a payer wrapper.

\section{Spraying Machine, Etc.}

For descriptions and illustrations of spraying pumps and other apparatus for applying insecticides, as well as further information with reforence to the preparation and application of insecticides, seo bulletins 21 and 43 of this station. 


\section{INDEX.}

Ants, No. 62, 152

Page.

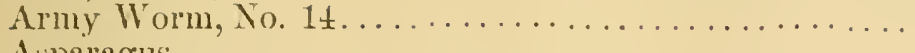

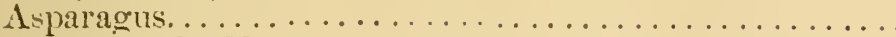

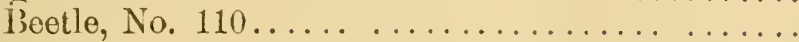

Beans.

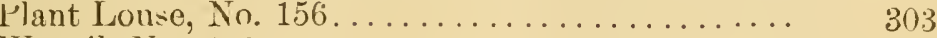

Weevil, No. $158 \ldots \ldots \ldots \ldots \ldots$............ 303

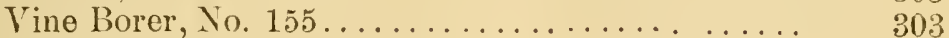

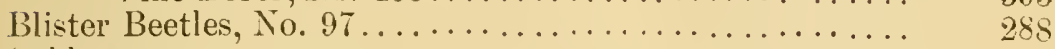

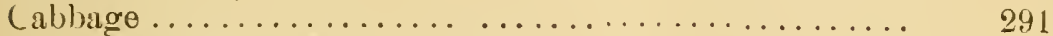

Caterpillar, Zebra, No. 123................. 295

Flea Beetle, wary striped, No. $117 \ldots \ldots \ldots \ldots \ldots .293$

Worm, purple striped, No. $120 \ldots \ldots \ldots \ldots \ldots \ldots .294$

"6 imported, No. $118 \ldots \ldots \ldots \ldots \ldots \ldots \ldots . .29 t$

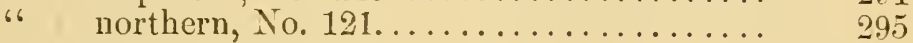

“ southern, No. 119.... . . . . . . . . . . 294

Maggots, No. 111................... 292

Plant Louse, No. 125.................. 296

Plusia Worm, No. $122 \ldots \ldots \ldots \ldots \ldots \ldots \ldots \ldots .295$

Bug, Harlequin, No. $124 \ldots \ldots \ldots \ldots \ldots \ldots \ldots \ldots . . \ldots 29$

Cadella, No. St....................... 283

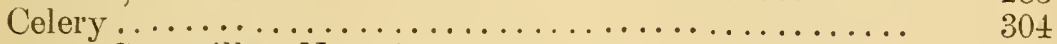

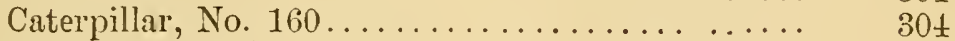

Plant Louse, No. $163 \ldots \ldots \ldots \ldots \ldots \ldots \ldots \ldots$......... 305

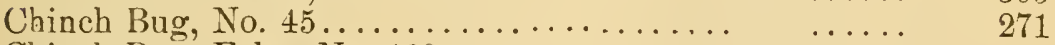

Chinch Bug, False, No. 139................... 300

Cigarette Beetle, No. 169.................... 307

Climbing Cutworms, Nos. 15 and $20 a \ldots \ldots \ldots \ldots \ldots$ 262, 263

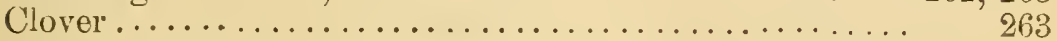

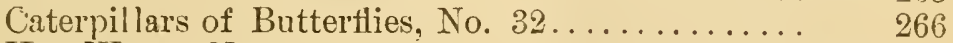

Hay Worm, No. 35.................. 267

Leaf Midge, No. $33 \ldots \ldots \ldots \ldots \ldots \ldots \ldots \ldots \ldots . .266$

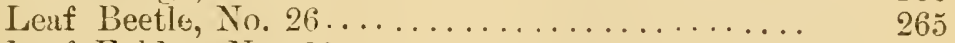

Leaf Folder, No. $30 \ldots \ldots \ldots \ldots \ldots \ldots . \ldots 266$

Looping Caterpillar, No. $31 \ldots \ldots \ldots \ldots \ldots \ldots .266$

Root Borer, No. 22................... 264

Stem Borer, No. 24.................... 264

Seed Midge, No. $34 \ldots \ldots \ldots \ldots \ldots \ldots \ldots \ldots \ldots . .267$ 
Corn, Indian .

Aphis, No. $76 \ldots \ldots \ldots \ldots \ldots \ldots \ldots . \ldots \ldots$

Cudella, No. $84 \ldots \ldots \ldots \ldots \ldots \ldots \ldots \ldots \ldots$. 283

Curculio, Sculptured, No. $71 \ldots \ldots \ldots \ldots \ldots \ldots \ldots .280$

Ear Worm, No 80 ................... 282

Grain Moth, Angoumois, No. $85 \ldots \ldots \ldots \ldots \ldots .284$

Indian Cetonia, No. 81............... . 282

Maggot, Blackhead, No. $66 \ldots \ldots \ldots \ldots \ldots \ldots .277$

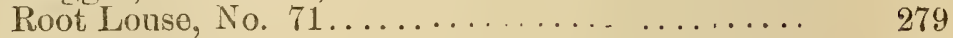

Root Worms......................... 278

Northern, No. $69 \ldots \ldots \ldots \ldots \ldots \ldots \ldots \ldots . . \ldots 278$

Southern, No. $70 \ldots \ldots \ldots \ldots \ldots \ldots \ldots .278$

Seed Maggot, No. 55.... . . . . . . . . . . 277

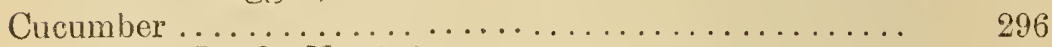

Flea Beetle, No. $136 \ldots \ldots \ldots \ldots \ldots \ldots \ldots \ldots . \ldots . \ldots . \ldots$

Striped Beetle, No. $134 \ldots \ldots \ldots \ldots \ldots \ldots \ldots . \quad 298$

Pickle Worm, No. $140 \ldots \ldots \ldots \ldots \ldots \ldots \ldots \ldots . . \quad 300$

Beotle, 12-Spotted, No. 135.............. 299

Cutworms, No. $7 \ldots \ldots \ldots \ldots \ldots \ldots \ldots \ldots \ldots \ldots . \ldots . \ldots 259$

Flea Beotles, Nos. 98, 150 and $168 \ldots \ldots \ldots \ldots \ldots$ 289, 301, 306

Fungus Gnats, No $88 \ldots \ldots \ldots \ldots \ldots \ldots \ldots \ldots \ldots \ldots$

Grain Louse, No. 56..................... 273

Grain Beetle, Saw-toothed, No. $60 \ldots \ldots \ldots \ldots \ldots \ldots \ldots . \ldots 275$

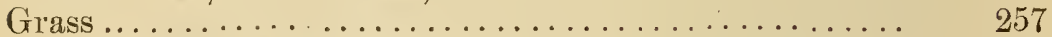

Maggot, Black-headed, No. $66 \ldots \ldots \ldots \ldots \ldots \ldots \quad 257$

Root Louse, No. $6 \ldots \ldots \ldots \ldots \ldots \ldots \ldots \ldots \ldots . \ldots \ldots$

Grasshoppers, No. $17 \ldots \ldots \ldots \ldots \ldots \ldots \ldots \ldots \ldots \ldots . \ldots \ldots 2$

Grasshoppers and Locusts, No. 16 and $17 \ldots \ldots \ldots \ldots . . . . .262$

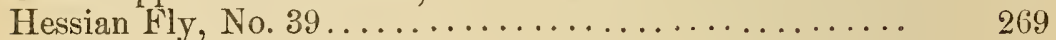

Indian Cetonia, No. $81 \ldots \ldots \ldots \ldots \ldots \ldots \ldots \ldots . \ldots \ldots . \ldots \ldots$

Locusts, Eastern Red-logged, No. 16............. 262

Meadow Grasshoppers, No. 17................ 262

Meadow Maggots, No. 3................... 258

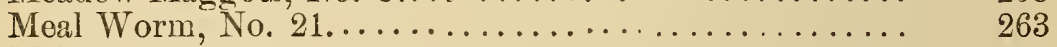

Melon............................... 296

Plant Louse, No. $138 \ldots \ldots \ldots \ldots \ldots \ldots \ldots \ldots \ldots$

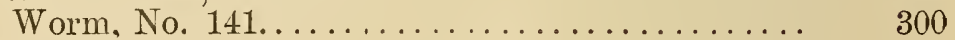

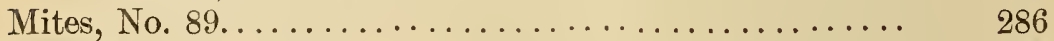

Negro Bug, No. 162......................... 305

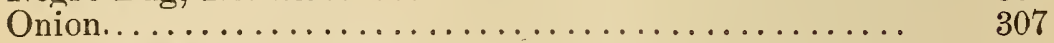

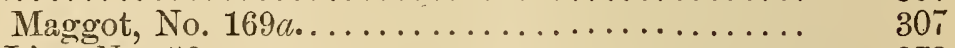

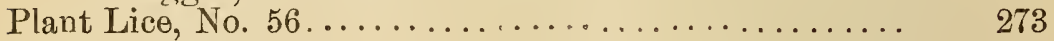

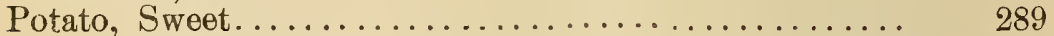

Tortoise Beetle, No. $108 \ldots \ldots \ldots \ldots \ldots \ldots \ldots . . \ldots 290$

Potato, Irish ....................... 284

Colorado Beetle, No. $96 \ldots \ldots \ldots \ldots \ldots \ldots \ldots . \ldots 28$

Scab Gnat Worm, No. $87 \ldots \ldots \ldots \ldots \ldots \ldots \ldots$ 28...

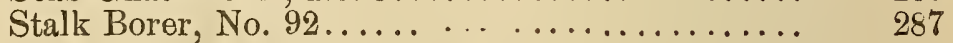

Leaf Beetle, Tree Lined, No. 99 . . . . . . . . . . 289 


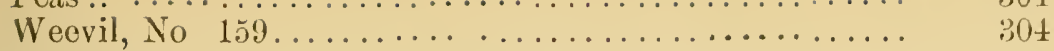

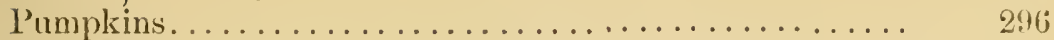

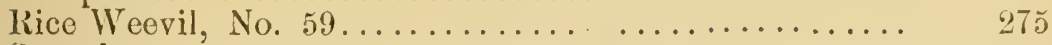

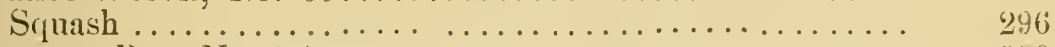

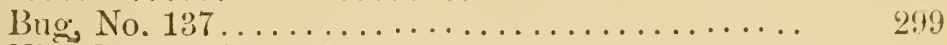

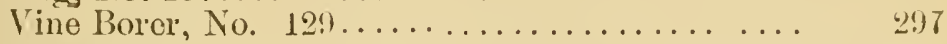

Sweet Putato............................. 289

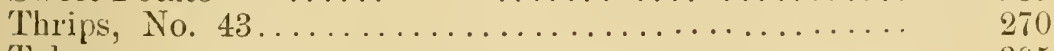

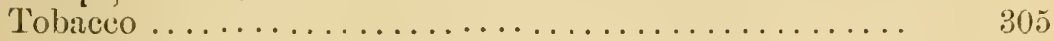

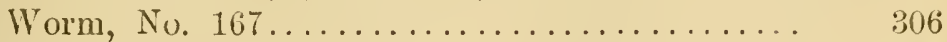

Tomatoes ................................. 301

Worm, No $1 \pm 7 \ldots \ldots \ldots \ldots \ldots \ldots \ldots \ldots \ldots \ldots$

Tortoise Beetle, No. 108 . . .................. 290

'Twelve-Spotted Cucumber Beetle, No. 135............ 299

Wavy Striped Flea Beetle, No. 117.... .......... 293

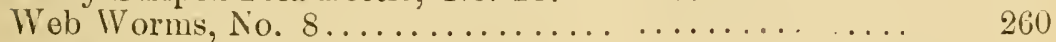

Weevil, Granary, No. $58 \ldots \ldots \ldots \ldots \ldots \ldots \ldots \ldots \ldots$

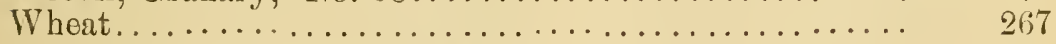

Companion Fly, No. 43. .............. 270

Frit Fly, American, No. $41 \ldots \ldots \ldots \ldots \ldots \ldots .270$

Grain Moth, Angoumois, No. $85 \ldots \ldots \ldots \ldots \ldots .284$

Head Pruner, No. 57.................. 274

Head Army Worm, No. 53............... 273

Hessian Fly, No. $39 . \ldots \ldots \ldots \ldots \ldots \ldots \ldots \ldots \ldots . \ldots 269$

Joint Worm, No. $36 \ldots \ldots \ldots \ldots \ldots \ldots \ldots \ldots \ldots . \ldots \ldots$

Midge, No. $52 \ldots \ldots \ldots \ldots \ldots \ldots \ldots \ldots \ldots \ldots \ldots . \ldots . \ldots . \ldots 273$

Saw Fly, No. $38 \ldots \ldots \ldots \ldots \ldots \ldots \ldots \ldots \ldots \ldots \ldots \ldots$

Stalk Borer, No. $73 \ldots \ldots \ldots \ldots \ldots \ldots \ldots \ldots \ldots .280$

Stem Grub, No. $49 . \ldots \ldots \ldots \ldots \ldots \ldots \ldots \ldots \ldots \ldots . \ldots 272$

Stem Maggot, No. $40 \ldots \ldots \ldots \ldots \ldots \ldots \ldots \ldots . \ldots 270$

Straw Worm, No. $38 \ldots \ldots \ldots \ldots \ldots \ldots \ldots \ldots \ldots . \ldots \ldots$

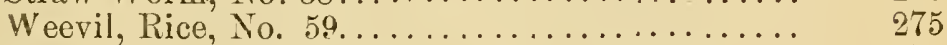

Wolf Moth, No. 55.................... 273

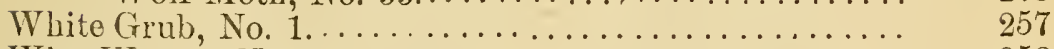

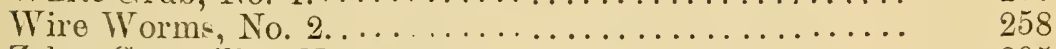

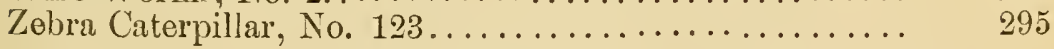



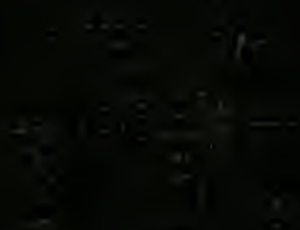

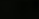

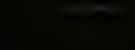

2

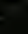

